Article

\title{
Mass spectrometry-based proteomic and immunoproteomic analyses of the Candida albicans hyphal secretome reveal diagnostic biomarker candidates for invasive candidiasis
}

\author{
Catarina Vaz ${ }^{1}$, Aida Pitarch ${ }^{1}$, Emilia Gómez-Molero ${ }^{2}$, Ahinara Amador-García ${ }^{1}$, Michael Weig ${ }^{2}$, Oliver Bader ${ }^{2}$, \\ Lucía Monteoliva ${ }^{1}$, Concha Gil 1,3
}

1 Department of Microbiology and Parasitology, Faculty of Pharmacy, Complutense University of Madrid and IRYCIS, 28040 Madrid, Spain; cataoliv@ucm.es (C.V.); apitavel@ucm.es (A.P.); ahinaram@ucm.es (A.A.G.); luciamon@ucm.es (L.M.); conchagil@ucm.es (C.G.)

2 Unidad de Proteómica, Facultad de Farmacia, Universidad Complutense de Madrid, Plaza Ramón y Cajal s/n, 28040 Madrid, Spainfor; conchagil@ucm.es (C.G.) ).

3 Institute for Medical Microbiology and Virology, University Medical Center Gottingen, Kreuzbergring 57, D-37075 Gottingen, Germany; emiliagomez803@hotmail.com (E.G.-M.); mweig@gwdg.de (M.W.); oliver.bader@med.uni-goettingen.de (O.B).

* Correspondence: luciamon@ucm.es; Tel.: +34 913941748

\begin{abstract}
Invasive candidiasis (IC) is associated with high morbidity and mortality in hospitalized patients if not diagnosed early. Long-term use of central venous catheters is a predisposing factor for IC. Hyphal forms of Candida albicans (the major etiological agent of IC) are related to invasion of host tissues. The secreted proteins of hyphae are involved in virulence, host interaction, immune response, and immune evasion. To identify IC diagnostic biomarker candidates, we characterized the C. albicans hyphal secretome by gel-free proteomic analysis, and further assessed the antibodyreactivity patterns to this subproteome in serum pools from 12 patients with non-catheter-associated IC (ncIC), 11 patients with catheter-associated IC (cIC), and 11 non-IC patients. We identified 301 secreted hyphal proteins stratified to stem from the extracellular region, cell wall, cell surface, or intracellular compartments. ncIC and cIC patients had higher antibody levels to the hyphal secretome than non-IC patients. Seven secreted hyphal proteins were identified to be immunogenic (Bgl2, Eno1, Pgk1, Glx3, Sap5, Pra1 and Tdh3). Antibody-reactivity patterns to Bg12, Eno1, Pgk1 and Glx3 discriminated IC patients from non-IC patients, while those to Sap5, Pra1 and Tdh3 differentiated between cIC and non-IC patients. These proteins may be useful for development of future IC diagnostic tests.
\end{abstract}

Keywords: Candida albicans; invasive candidiasis; secretome; secreted proteins; hypha; diagnosis; biomarkers; immunoproteomics; SERPA; serologic response.

\section{Introduction}

Candida albicans is an opportunistic fungal pathogen that can grow as yeast-form, pseudohyphal, or hyphal cells, each under specific host or environmental stimuli. Hyphal forms are the most often observed morphology of this polymorphic fungus in tissue biopsies and histological analysis of clinical lesions [1]. It appears to be linked to the hyphae increased ability to adhere to host cells and invade host tissues than do other morphotypes [2, 3]. In contrast, yeast-form cells usually contribute to bloodstream dissemination [4].

C. albicans is the major etiologic agent of invasive candidiasis (IC), which is associated with high morbidity and mortality in immunocompromised and critically ill patients $[5$, 
6]. There are several predisposing factors for IC. These are related to $(i)$ host microbiota alteration (e.g., long-term treatment with broad-spectrum antibiotics), (ii) rupture of the cutaneous and gastrointestinal barriers (e.g., organ transplants or use of central venous catheters), and (iii) impairment of host defenses (e.g., cancer, neutropenia, chemotherapy or corticosteroid therapy) $[5,7]$. Colonization is a prerequisite for acquisition of IC [8]. Long-term use of central venous catheters enables Candida cells to translocate from mucocutaneous sites into the bloodstream, facilitating invasion of host tissues and organs. Catheter-related bloodstream infections caused by Candida spp. are common and show life-threatening complications [9-11].

Detection of IC at an early stage of the disease is crucial for optimizing antifungal therapy and improving the clinical outcomes of patients. The gold standards for diagnosing IC are still blood culture with subsequent species identification and tissue biopsies. However, blood cultures can take 2-5 days to attain a decisive result and are not useful for the diagnosis of deep-seated candidiasis in the absence of candidemia; in contrast histopathological examination is often a too invasive method for critically ill patients [7, 12]. Matrix-assisted laser desorption-time of flight mass spectrometry (MALDI-TOF MS) is a useful technology for the identification of C. albicans species, but requires positive cultures [13]. PCR-based technologies used for Candida DNA amplification have high specificity and sensitivity for IC diagnosis, but lack standardized protocols [14]. The T2 magnetic resonance (T2Candida) assay is a new diagnostic method of IC that accurately detects the most common pathogenic Candida species [15, 16], but its sensitivity decreases in the absence of intact Candida cells in whole-blood samples [17]. Other non-culture methods mainly include the detection of Candida mannans and 1,3- $\beta$ D-glucan as well as host-derived biomarkers, such as human antibodies against Candida antigens [7]. There is therefore a general effort being made for the discovery of novel useful biomarkers, including the detection of suitable biomolecules both from pathogen and from the host [7]. These could be used as a faster diagnostic method because there is no need to culture the microorganism.

Classical immunoproteomics or serological proteome analysis (SERPA) are widely used techniques for screening panels of antibody biomarkers for diverse infectious diseases [18-22]. It enables the characterization of the immunome of any microorganism, which is the subset of its proteome targeted by the immune system [23]. Our group has applied this technique, which combines two-dimensional gel electrophoresis (2-DE) with Western blotting and mass spectrometry (MS), to identify biomarker candidates of IC [23$25]$, and has previously shown that the use of multiple biomarker panels should be the path to choose for development of better diagnostic and prognostic assays for IC [26-28]. Most of immunoproteomic studies for the search of new biomarker candidates for IC were performed with intracellular or cell wall proteins from C. albicans [23, 24, 29-31]. A SERPA study used the secretome of C. albicans yeasts and hyphae as a source of antigens, and showed that hyphal secreted proteins were more abundant and immunogenic than yeast secreted proteins [32]. Despite the reduced number of sera used, this study identified a core set of antibody mediated reactivity against 19 C. albicans secreted proteins, seven of which could serve for the diagnosis of candidemia (Xog1, Lip4, Asc1, Met6, Tsa1, Tpi1, and Prx1).

C. albicans secretes many proteins involved in, e.g, the degradation of host proteins, lipids, or carbohydrates, in acquisition of zinc or other essential ions, and protecting against microbial peptides [33-36]. Proteins can be secreted either by the classical secretory pathway or by alternative routes of exportation [37]. Our group has described the secretion of classical cytoplasmic proteins (lacking a signal peptide) inside extracellular vesicles $(\mathrm{EV})[34,38]$. Some of these proteins are 'moonlighting' as they have different functions depending on their subcellular location $[39,40]$. Fungal EVs also interact with the host [41]. A recent work has demonstrated that the biofilms of C. albicans defective mutants in the endosomal sorting complexes produced less EVs, and these biofilms were more resistant to antifungal drugs, which helped to understand the role in EVs in cell-cell signaling [42]. Taking into account the important role of secreted proteins during 
interaction with the host, these could be useful for the future design of vaccine strategies and diagnostic tests for IC [34, 38].

In this work, we performed a proteomic analysis to characterize the C. albicans hyphal secretome. We also examined the serological response to this subproteome in patients with IC associated or not with catheters with the purpose of identifying potential biomarker candidates for IC diagnosis.

\section{Materials and Methods}

\subsection{Study population and serum samples}

Serum specimens were obtained from the Institute for Medical Microbiology and Virology, University Medical Center Göttingen in Germany. These were pooled into three groups: (i) the non-catheter-associated IC (ncIC) group, which included sera from $12 \mathrm{ncIC}$ patients, (ii) the catheter-associated IC (cIC) group, which comprised sera from 11 cIC patients, and (iii) the negative control (non-IC) group, which encompassed sera from 11 matched patients with similar age and sex, and being from the same hospital wards as those from ncIC or cIC, but without IC. ncIC was defined as isolation of the same Candida species in one or more blood cultures and/or in culture from a sterile liquid or organ. Patients were defined as having cIC if they had the same Candida species in one or more catheter cultures. Only sera from patients that had previously been tested negative for HIV and hepatitis were included. The use of these sera in diagnostic research areas was approved by the University Ethics Committee (UMG-17/9/08) and patients consented into the use of left-over diagnostic material. All sera were stored at $-80^{\circ} \mathrm{C}$ until use. Baseline characteristics of patients are shown in Table S1.

\subsection{Isolation of C. albicans hyphal secreted proteins}

C. albicans strain SC5314 was maintained in yeast extract-peptone-dextrose (YPD) plates ( $2 \%$ glucose, $1 \%$ yeast extract, $2 \%$ peptone, and $2 \%$ agar) at $30^{\circ} \mathrm{C}$. Cells from a yeast colony were grown overnight in synthetic defined (SD) medium supplemented with amino acids ( $2 \%$ glucose, $0.5 \%$ ammonium sulfate, $0.17 \%$ yeast nitrogen base, $0.19 \%$ amino acids mix without uracil, and $0.01 \%$ uracil) at $180 \mathrm{rpm}$ and $30^{\circ} \mathrm{C}$. Pre-inoculum was adjusted to an optical density of 0.1 , and incubated for $6 \mathrm{~h}$. Cells were recovered, washed in PBS, and counted in Neubauer chamber. Then, $5 \times 10^{5}$ cells $/ \mathrm{mL}$ were incubated for $18 \mathrm{~h}$ at $100 \mathrm{rpm}$ and $37^{\circ} \mathrm{C}$ in two different media: $(i)$ salt medium+GlcNac, which included salt medium $(0.45 \% \mathrm{NaCl}, 0.08 \%$ yeast nitrogen base, $0.25 \%$ ammonium sulfate, $\mathrm{pH} 7.4)$ supplemented with $2.5 \mathrm{mM} \mathrm{N}$-acetylglucosamine (GlcNac) [43]; and (ii) Lee medium, pH 6.7 [44]. Cells were centrifuged at $5000 \mathrm{rpm}$ (without break) for $40 \mathrm{~min}$ at $4^{\circ} \mathrm{C}$, and the supernatant was recovered. From this moment forward, all steps were performed on ice. Hyphal morphology was confirmed by contrast microscopy, and cell lysis by propidium iodide (PI) staining. The supernatant was double filtered using $0.45 \mu \mathrm{m}$ low protein binding filters (Millipore) to eliminate cells that were not yet removed by centrifugation. One tablet of protease inhibitor cocktail (Thermo Scientific Halt) dissolved in water and $0.1 \mathrm{M}$ phenylmethanesulfonyl fluoride (PMSF) was added to the filtrate. One $\mathrm{mL}$ of the filtrate was plated and when one or more colony forming unit (CFU) grew on YPD plates, the supernatant was discarded. Supernatant containing the secreted proteins was concentrated approximately 100 times using centrifugal filter devices (10 kDa-pore Centricon Plus-70, Millipore). The supernatant was frozen until precipitation. This was performed by incubation of the sample with a fourth part of trichloroacetic acid (TCA; $100 \% \mathrm{w} / \mathrm{v}$ ) for $1 \mathrm{~h}$ in ice. Then, it was centrifuged at $10000 \mathrm{~g}$ for $30 \mathrm{~min}$ at $4^{\circ} \mathrm{C}$. Supernatant was discarded. Ultrapure water was added to the pellet and vortexed. After this, chilled washing buffer from the 2-D clean-up kit (GE Healthcare) was added with $5 \mu \mathrm{L}$ of wash additive, vortexed and kept at $-20^{\circ} \mathrm{C}$ overnight. Protein sample was then centrifuged, and the supernatant discarded. The pellet was dried (no longer than 5 minutes) and resuspended in rehydration buffer (7 M urea, $2 \mathrm{M}$ thiourea, 2\% 3-[(3cholamidopropyl)dimethyl-ammonio]-1-propane sulfonate (CHAPS), $65 \mathrm{mM}$ 
dithioerythritol (DTE), 0.5\% immobilized $\mathrm{pH}$ gradient (IPG) buffer $\mathrm{pH}$ 3-10 (GE Healthcare), and $0.002 \%$ bromophenol blue) [45]. The different obtained secretomes were pooled in two batches (S1 and S2).

2.3. Protein separation by sodium dodecyl sulfate-polyacrylamide gel electrophoresis (SDS-PAGE)

The different secretome samples were separated by SDS-PAGE following standard protocols. Gels were stained either with a silver stain kit (BioRad) or with Coomassie brilliant blue as follows. Briefly, gels were fixed with $50 \%$ methanol and $10 \%$ glacial acetic acid. Then, gels were stained with $0.1 \%$ Coomassie brilliant blue R-250, 50\% methanol and $10 \%$ acetic acid for $1 \mathrm{~h}$ at room temperature, and destained again with $40 \%$ methanol and $10 \%$ acetic acid.

\subsection{Protein identification by liquid chromatography-tandem mass spectrometry (LC-MS/MS) analysis}

Coomassie brilliant blue-stained protein bands from $20 \mu \mathrm{g}$ of the two secretome batches (S1 and S2) were cut from the interface between the stacking and resolving layers of a SDS-PAGE gel (with a larger stacking layer). These were in-gel destained, reduced with DTT, alkylated with iodoacetamide, and digested with trypsin (Roche) overnight at $37^{\circ} \mathrm{C}$ as described [46]. Samples were then freeze-dried in a Speed-vac, resuspended in $2 \%$ acetonitrile and $0.1 \%$ formic acid, and stored at $-20{ }^{\circ} \mathrm{C}$ until nanoLC-MS/MS analysis.

Peptides were then analyzed by reversed-phase LC-electrospray ionization MS/MS (RP-LC-ESI-MS/MS) in an EASY-nLC 1000 system coupled to the Q-Exactive HF mass spectrometer through the nano-Easy spray source (Thermo Scientific). Peptides were loaded first onto a Acclaim PepMap 100 trapping column (20mm x $75 \mu \mathrm{m}$ ID, $3 \mu \mathrm{m}$ C18 resin with $100 \AA$ pore size; Thermo Scientific) using buffer A (mobile phase A: $2 \%$ acetonitrile and $0.1 \%$ formic acid), and then separated and eluted on a C18 resin analytical column NTCC (150 mm x $75 \mu \mathrm{m}$ ID, $3 \mu \mathrm{m}$ C18 resin with $100 \AA$ pore size; Nikkyo Technos Co., Ltd.) with an integrated spray tip. A 150 min gradient from 5\% to 35\% buffer B (100\% acetonitrile, $0.1 \%$ formic acid) in buffer A at a constant flow rate of $250 \mathrm{~nL} / \mathrm{min}$ was used. Data acquisition was performed on a Q-Exactive HF mass spectrometer. Data were acquired using an ion spray voltage $1.8 \mathrm{KV}$ and ion transfer temperature of $250^{\circ} \mathrm{C}$. All data were acquired using data-dependent acquisition (DDA) and in positive mode with Xcalibur 4.0 software. For $\mathrm{MS}^{2}$ scan, the top 15 most abundant precursors with charges of 2 to $4+$ in MS $^{1}$ scans were selected for higher energy collisional dissociation (HCD) fragmentation with a dynamic exclusion of $20 \mathrm{~s}$. The $\mathrm{MS}^{1}$ scans were acquired at $\mathrm{m} / \mathrm{z}$ range of 350-1600 Da with mass resolution of 60000 and automatic gain control (AGC) target of $3 \mathrm{E} 6$ at a maximum ion time (ITmax) of $60 \mathrm{~ms}$. The threshold to trigger MS ${ }^{2}$ scans was $2 \mathrm{E} 3$. The normalized collision energy (NCE) was 27\%. The resolved fragments were scanned at mass resolution of 30000 and AGC target value of 1E5 in an ITmax of $100 \mathrm{~ms}$.

Peptide identification from raw data was carried out using Mascot v.2.6.1 search engine through the Protein Discoverer 2.2 software (Thermo Scientific). A database search was performed against Candida Genome Database (CGD) Assembly 21 (6 221 sequences). The following parameters were used for the searches: tryptic cleavage after Arg and Lys, up to two missed cleavage sites allowed, and tolerances of $10 \mathrm{ppm}$ for precursor ions and 0.02 Da for MS/MS fragment ion. The searches were performed allowing optional methionine oxidation and methionine loss plus acetyl protein $N$-terminal, and fixed carbamidomethylation of cysteine. Search against decoy database (integrated decoy approach) was used to calculate FDR. The Mascot scores were adjusted by the Mascot percolator algorithm. The acceptance criteria for protein identification were a FDR $<1 \%$ and at least one peptide identified with high confidence (confidence interval, CI > 95\%). Only proteins present in both secretome batches (S1 and S2) and identified with at least two peptides were selected for further analysis. The mass spectrometry proteomics data have been deposited to the ProteomeXchange Consortium via the PRIDE partner repository with the dataset identifier PXD013933 (Username: reviewer96172@ebi.ac.uk; 
Password: Im3U2aHp).

\subsection{Indirect enzyme-linked immunosorbent assay (ELISA)}

Indirect ELISA for measurement of serum levels of IgG antibodies to the C. albicans secretome was performed as described previously [47] with some modifications. Wells of microtiter plates were coated with $5 \mu \mathrm{g} / \mathrm{mL}$ of $C$. albicans hyphal secreted proteins and cytoplasmic proteins (prepared as reported in [48]) in $0.1 \mathrm{M}$ carbonate buffer $\mathrm{pH} 9.6$ overnight at $4^{\circ} \mathrm{C}$, and then washed three times with washing buffer (PBS containing $0.05 \%$ Tween-20). Wells were then blocked with PBS containing $1 \%$ bovine serum albumin (BSA) for $2 \mathrm{~h}$ at $37^{\circ} \mathrm{C}$. These were washed three times with washing buffer, and then incubated with serial dilutions (from 1:250 to 1:1 024 000) of the different serum pools (ncIC, cIC and non-IC) in assay buffer (PBS containing $0.1 \%$ BSA and $0.05 \%$ Tween-20) for $2 \mathrm{~h}$ at $37^{\circ} \mathrm{C}$. After this, wells were washed six times with washing buffer, and then incubated with a horseradish peroxidase (HRP)-labelled anti-human IgG antibody (GE Healthcare) at a dilution of 1:3000 in assay buffer at $37^{\circ} \mathrm{C}$ for $1 \mathrm{~h}$. Wells were rinsed three times with washing buffer and once with PBS. They were developed with $0.04 \%$ o-phenylenediamine dihydrochloride (OPD, Sigma) in $0.05 \mathrm{M}$ phosphate-citrate buffer, $\mathrm{pH}$ 5.0, containing $0.04 \%$ hydrogen peroxide. The reaction was stopped with $3 \mathrm{~N}$ sulfuric acid. The absorbance was measured in a microplate reader at $490 \mathrm{~nm}$ (Bio-Rad). The IgG antibody titer was calculated as the inverse of the highest dilution at which the absorbance was twofold greater than the background.

\subsection{Immunoproteomic analysis or SERPA}

SERPA was carried out as reported previously [32,49] with some modifications. In brief, $100 \mu \mathrm{g}$ of $C$. albicans hyphal secreted proteins were actively rehydrated in Immobiline $\mathrm{pH} 3$ to 11 nonlinear (NL) gradient DryStrips (7 cm long, GE Healthcare). Isoelectric focusing (IEF) was performed on IPGphor device (GE Healthcare) using the following program for analytical gels: $30 \mathrm{~V}$ for $3.5 \mathrm{~h}, 60 \mathrm{~V}$ for $3.5 \mathrm{~h}, 60-300 \mathrm{~V}$ for $3 \mathrm{~h}, 300$ $600 \mathrm{~V}$ for $4 \mathrm{~h}, 600-1000 \mathrm{~V}$ for $4 \mathrm{~h}, 1000-8000 \mathrm{~V}$ for $4 \mathrm{~h}$, and $8000 \mathrm{~V}$ for $6 \mathrm{~h}$. IPG strips were reduced with balancing solution (50 mM Tris- $\mathrm{HCl}, \mathrm{pH} 6.5,6 \mathrm{M}$ urea, 30\% glycerol, 2\% SDS) containing 2\% DTT for $30 \mathrm{~min}$, and then alkylated with balancing solution containing $2.5 \%$ iodoacetamide for $30 \mathrm{~min}$ in dark. The second dimension (SDS-PAGE) was carried out using a $10 \%$ polyacrylamide gel. After separating the secreted proteins by 2-DE, they were transferred to a nitrocellulose membrane (GE Healthcare) at $100 \mathrm{~V}$ for 1 h. Blots were then stained with Sypro Ruby protein blot stain (BioRad), and scanned using Typhon scanner (GE Healthcare). They were blocked with $5 \%$ skin milk in PBS at $4^{\circ} \mathrm{C}$ overnight. Blots were rinsed with PBS and incubated with serum pools (ncIC, cIC and non-IC) at three sequential dilutions 1:500, 1:250 and 1:100 in TPBS (PBS containing 0.1\% Tween-20) with $0.1 \%$ skin milk for $2 \mathrm{~h}$. After 4 washing steps (20 min each) with TPBS, blots were incubated with IRDye $800 \mathrm{~W}$ conjugated goat anti-human IgG antibody (LICOR Biosciences) at a dilution of 1:5000 for $1 \mathrm{~h}$. After 4 washing steps with TPBS (15 min each), Odyssey system was used to detect the fluorescence signals.

For identification of immunogenic protein spots, $190 \mu \mathrm{g}$ of protein were separated by 2-DE as described above using a slightly modified IEF program: $30 \mathrm{~V}$ for $3.5 \mathrm{~h}, 60 \mathrm{~V}$ for $3.5 \mathrm{~h}, 60-300 \mathrm{~V}$ for $3 \mathrm{~h}, 300-600 \mathrm{~V}$ for $4 \mathrm{~h}, 600-1000 \mathrm{~V}$ for $4 \mathrm{~h}, 1000-8000 \mathrm{~V}$ for $4 \mathrm{~h}$, and 8000 $\mathrm{V}$ for $9.5 \mathrm{~h}$. Preparative 2-DE gels were stained with colloidal Coomassie blue as reported [49]. Briefly, gels were fixed with 50\% methanol and $2 \%$ phosphoric acid for 30 min, and then washed with water twice for 10 min each. Gels were equilibrated with $33 \%$ methanol, $3 \%$ phosphoric acid and $17 \%$ ammonium sulfate for $40 \mathrm{~min}$, and $6.6 \%$ Coomassie brilliant blue G-250 in methanol was added to reach $0.066 \%$ of dye. After overnight incubation, excess dye was eliminated with successive washes with water.

Immunogenic protein spots of interest were manually excised from the preparative 2-DE gels, in-gel destained, reduced, alkylated and digested as described above. These were identified by MALDI-TOF MS analyses on a 4800 Plus Proteomics Analyzer MALDITOF mass spectrometer (Applied Biosystems) as reported previously [46]. The MALDI- 
TOF operated in positive reflector mode with an accelerating voltage of $20000 \mathrm{~V}$. All mass spectra were internally calibrated using peptides from the auto-digestion of trypsin. Database searches of MS data for protein identification were carried out using Mascot 2.3 (www.matrixscience.com) through the software Global Protein Server v3.6 (ABSciex) using CGD (assembly 22; 12421 sequences; 6015970 residues). Search parameters were carbamidomethyl cysteine as fixed modification; oxidized methionine as variable modification; peptide mass tolerance of $100 \mathrm{ppm}$; and one missed trypsin cleavage site. The probability scores were greater than the score fixed by Mascot as significant with a $p$ value $<0.05$. For the identification of the proteins from the upper left zone of the preparative 2-DE gels, four bands were cut, destained, reduced, alkylated and in-gel digested with trypsin, and then identified by LC-MS/MS analysis as detailed above.

\subsection{Bioinformatic analysis}

NSAF (normalized spectral abundance factor) was calculated for each LC-MS/MSidentified protein [50]. CGD was the main database used for the functional protein classification. Signal peptides were predicted using SignalP4.1 software (www.cbs.dtu.dk/services/SignalP/). The presence of a signal peptide was confirmed in CGD database. Glycosylation sites were predicted using NetNGlyc 1.0 server prediction program (which examines the sequence context of Asn-Xaa-Ser/Thr) and NetNGlyc 4.0 server prediction software (which produces predictions of the type GalNac Oglycosylation). Venn diagrams were performed using the Venny 2.1 tool (bioinfogp.cnb.csic.es/tools/venny/).

Antibody titers were $\log _{2}$-transformed to approximate normal distribution prior to data analysis. The differences in the mean $\log ^{2} \operatorname{IgG}$ antibody titers among the study groups were assessed using one-way analysis of variance (ANOVA) with Tukey's multiple comparison correction. $p$ value less than 0.05 was considered significant (two-sided).

\section{Results}

\subsection{Isolation of the C. albicans hyphal secretome}

To set up the best conditions for the isolation of C. albicans hyphal secreted proteins, yeast cells were grown for $18 \mathrm{~h}$ in two different media (salt medium+GlcNac and Lee medium $\mathrm{pH}$ 6.7). Hyphal cell forms were observed in both media. Cell integrity measurements by propidium iodide revealed $\sim 3 \%$ of cell lysis in salt medium+GlcNac, and $\sim 7 \%$ in Lee medium, pH 6.7 (Figure S1A). Similar hyphal secreted protein yield was obtained in salt medium+GlcNac $(17.1 \mu \mathrm{g}$ per $500 \mathrm{~mL})$ and Lee medium $(16.8 \mu \mathrm{g}$ per 500 $\mathrm{mL}$ ). However, hyphal secreted protein patterns were different in both media (Figure S1B). Preliminary LC-MS/MS analysis showed a slightly higher number of identified proteins in Lee medium than in salt medium+GlcNac (115 vs 100 proteins). A total of 43 proteins were common to both media (Figure S1C). Despite slightly higher percentage of cell lysis, bioinformatic analysis using SignalP 4.1 highlighted higher percentage of secreted proteins with signal peptide in Lee medium than in salt medium+GlcNac $(23.4 \%$ vs $2 \%$; Table S2). Because of the higher number of proteins with signal peptide, Lee medium was used for secretome extraction.

After medium selection, the protocol was further optimized by reducing shaking conditions of cell growth and removing the centrifugation break in order to obtain minimal cell lysis. Ten fluorescence images were taken before obtaining each secretome to estimate the cell lysis percentage. This protocol reduced lysis to $1-2 \%$ (Figure S1D). Secreted protein patterns were similar among different replicates ( $n=10$; Figure S2). These were batched in two pools with five replicates each (S1 and S2), and used for the different analysis.

\subsection{Gel-free LC-MS/MS analysis of the C. albicans hyphal secretome}

Hyphal secreted proteins in Lee medium from S1 and S2 were in-gel digested and further analyzed by LC-MS/MS. A total of 301 proteins were identified in both replicate 
batches with at least 2 peptides (Table S3). NSAF was used to rank proteins regarding their relative abundance (with values from 0 to 1 ). NSAF correlation analysis between the proteins identified in S1 and S2 showed that both secretome batches were very similar to each other in terms of protein relative abundance (Figure 1A). The 50 most abundant proteins are shown in Figure 1B.

GO enrichment analysis of the identified hyphal secreted proteins highlighted that the most significantly represented biological process was carbohydrate metabolism (including proteins involved in glycolysis and cell wall polymer metabolism). Interaction with the host, cellular response to oxidative stress and pathogenesis were other enriched biological processes found in the identified proteins (Figure 2A). Proteins from the extracellular part of the cell were enriched in the secretome batches (Figure 2B). A total of 37 proteins were annotated to be present only in the extracellular region, 107 proteins were annotated only to the cytoplasmic lumen, and 93 proteins were annotated to both localizations (Figure 2C and Table 1). As expected, $43 \%$ of the proteins annotated in the extracellular region presented signal peptide, while $11 \%$ of the proteins annotated in both locations had signal peptide. Only four proteins annotated to the intracellular region were predicted to have signal peptide; these corresponded to uncharacterized ORFs. A higher percentage of immunogenic proteins were identified among those located in the extracellular region $(27 \%)$ or in both cellular locations $(31 \%)$ than among those located intracellularly $(6.5 \%$; Table 1$)$. 
A

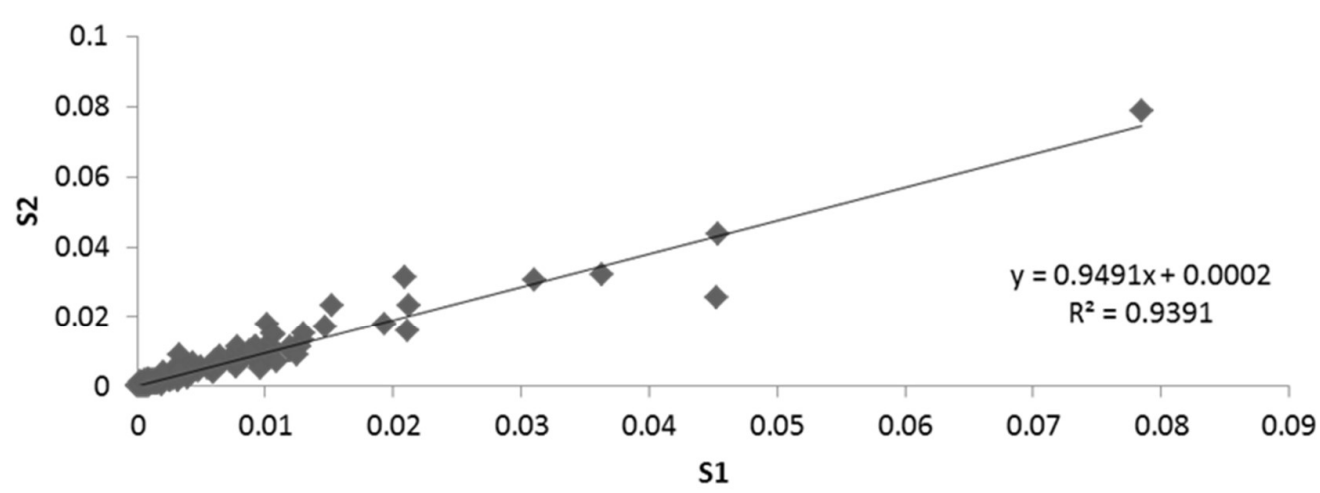

B

\begin{tabular}{|c|c|c|c|c|c|c|c|c|c|c|c|}
\hline Rank & $\begin{array}{c}\text { Systematic } \\
\text { Name }\end{array}$ & $\begin{array}{l}\text { Standard } \\
\text { Name }\end{array}$ & $\begin{array}{c}\text { Assermbly } 19 / 21 \\
\text { Identifier }\end{array}$ & NSAF & $\begin{array}{c}\text { Signal } \\
\text { peptide }\end{array}$ & Rank & $\begin{array}{c}\text { Systermatic } \\
\text { Name }\end{array}$ & $\begin{array}{l}\text { Standard } \\
\text { Name }\end{array}$ & $\begin{array}{l}\text { Assembly } 19 / 21 \\
\text { Identifier }\end{array}$ & NSAF & $\begin{array}{c}\text { Signal } \\
\text { peptide }\end{array}$ \\
\hline 1 & C1_08500C_A & Eno1 & orf19.395 & 0.079 & & 26 & C5_00370W_A & Cof1 & orf19.953.1 & 0.009 & \\
\hline 2 & C6_00750C_A & Pgk1 & orf19.3651 & 0.045 & & 27 & C1_01350C_A & Tif & orf19.3324 & 0.009 & \\
\hline 3 & C6_03030W_A & Sap5 & orf19.5585 & 0.035 & $x$ & 28 & C4_07180W_A & Ubi3 & orf19.3087 & 0.009 & \\
\hline 4 & C7_02380C_A & Cyp1 & orf19.6472 & 0.034 & & 29 & C4_06570C_A & Pdc11 & orf19.2877 & 0.009 & \\
\hline 5 & C4_01750C_A & Fba1 & orf19.4618 & 0.031 & & 30 & C5_04270C_A & Sah1 & orf19.3911 & 0.009 & \\
\hline 6 & C2_10030C_A & Mp65 & orf19.1779 & 0.026 & $x$ & 31 & C5_02860C_A & Grp2 & orf19.4309 & 0.009 & \\
\hline 7 & C1_13860C_A & Gnd1 & orf19.5024 & 0.022 & & 32 & C6_02240C_A & Rpl10a & orf19.3465 & 0.009 & \\
\hline 8 & C3_07440W_A & Tpi1 & orf19.6745 & 0.019 & & 33 & C1_02480W_A & Pmm1 & orf19.2937 & 0.008 & \\
\hline 9 & C3_06870W_A & Tdh3 & orf19.6814 & 0.019 & & 34 & C2_08810C_A & Ipp1 & orf19.3590 & 0.008 & \\
\hline 10 & C3_06180C_A & Tsal & orf19.7417 & 0.019 & & 35 & C1_04300C_A & Ssa2 & orf19.1065 & 0.008 & \\
\hline 11 & C4_03470C_A & Ece1 & orf19.3374 & 0.016 & & 36 & C1_02590C_A & Snz1 & orf19.2947 & 0.007 & \\
\hline 12 & C4_06980W_A & Pra1 & orf19.3111 & 0.014 & $x$ & 37 & C7_02570C_A & Rbp1 & orf19.6452 & 0.007 & \\
\hline 13 & CR_03720W_A & Tal1 & orf19.4371 & 0.014 & & 38 & C1_13480W_A & Hsp70 & orf19.4980 & 0.007 & \\
\hline 14 & C2_05460W_A & Cdc19 & orf19.3575 & 0.013 & & 39 & C2_10110W_A & Cyc1 & orf19.1770 & 0.007 & \\
\hline 15 & CR_10350C_A & $\operatorname{Tr} \times 1$ & orf19.7611 & 0.013 & & 40 & C7_00750W_A & $\mathrm{Acb} 1$ & orf19.7043.1 & 0.007 & \\
\hline 16 & C1_07900W_A & Coil & orf19.5063 & 0.013 & $x$ & 41 & C1_03510C_A & orf19.3053 & orf19.3053 & 0.007 & \\
\hline 17 & C1_08030W_A & Pfy1 & orf19.5076 & 0.012 & & 42 & C4_02410C_A & Ahp1 & orf19.2762 & 0.007 & \\
\hline 18 & C3_06360C_A & Cyp5 & orf19.7421 & 0.012 & $x$ & 43 & C3_05000W_A & Rdi1 & orf19.5968 & 0.006 & \\
\hline 19 & CR_06340C_A & Pgi1 & orf19.3888 & 0.011 & & 44 & CR_10100C_A & Ino1 & orf19.7585 & 0.006 & \\
\hline 20 & C1_03220C_A & Bmh1 & orf19.3014 & 0.011 & & 45 & C1_13940W_A & Sim1 & orf19.5032 & 0.006 & $x$ \\
\hline 21 & C2_03270W_A & Gpm1 & orf19.903 & 0.011 & & 46 & C1_02990C_A & Xog 1 & orf19.2990 & 0.006 & $x$ \\
\hline 22 & CR_01620C_A & Met6 & orf19.2551 & 0.010 & & 47 & C7_01250W_A & Asc1 & orf19.6906 & 0.006 & \\
\hline 23 & CR_04510W_A & $\mathrm{H} \times \mathrm{k} 2$ & orf19.542 & 0.010 & & 48 & C1_03190C_A & Ecm33 & orf19.3010.1 & 0.005 & $x$ \\
\hline 24 & C5_02890W_A & Ynk1 & orf19.4311 & 0.010 & & 49 & C2_03100W_A & $\mathrm{Eft} 2$ & orf19.5788 & 0.005 & \\
\hline 25 & C7_00110W_A & Sod3 & orf19.7111.1 & 0.010 & & 50 & C3_05130C_A & Thi4 & orf19.5986 & 0.005 & \\
\hline
\end{tabular}

Figure 1. Proteins identified in the two secretome batches (S1 and S2) with at least two peptides by the gel-free LCMS/MS analysis. (A) Correlation of NSAF values of the proteins from both secretome batches. (B) Protein ranking of the 50 most abundant proteins according to the NSAF average of the two secretome batches. 
A

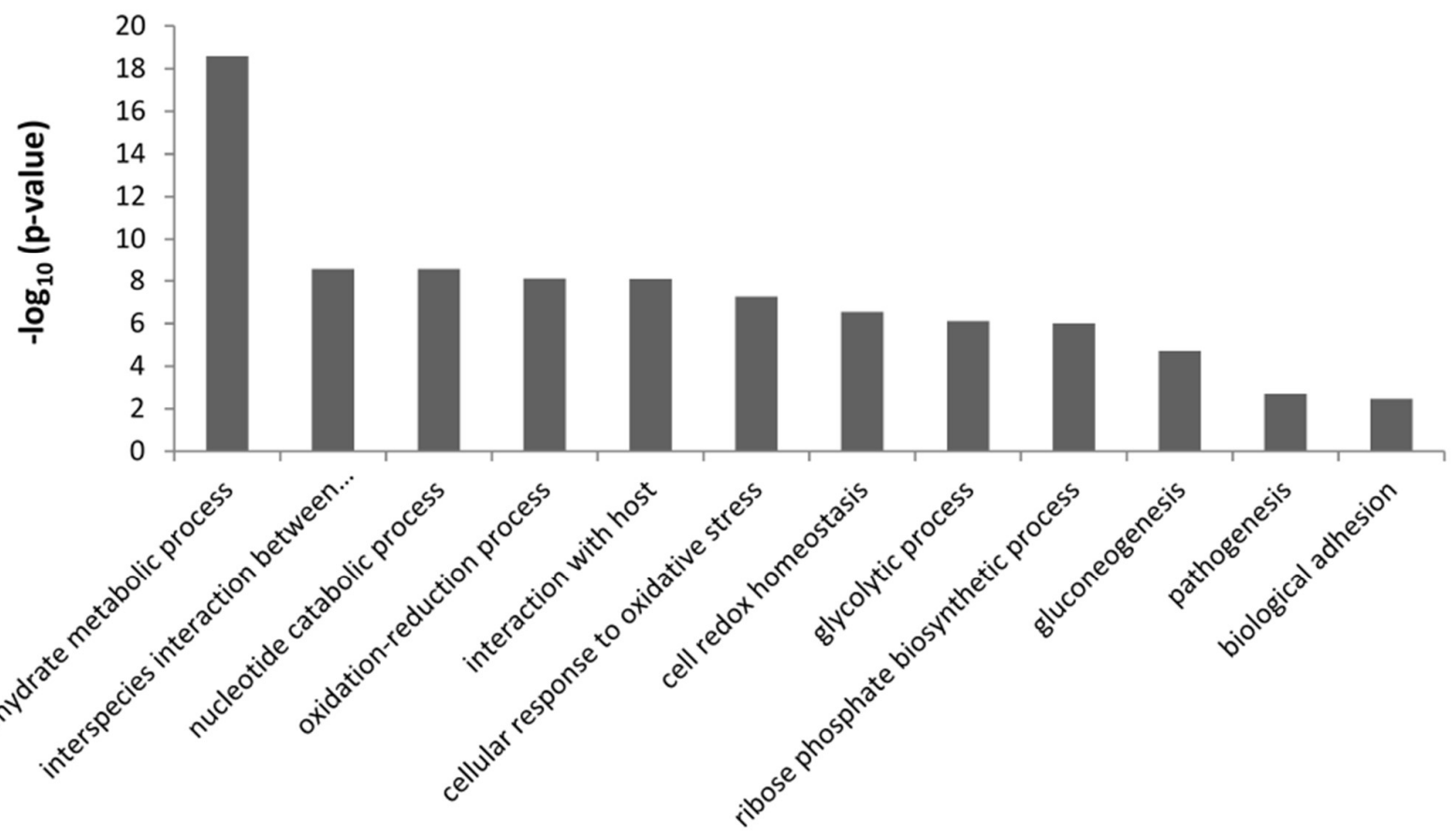

B

C
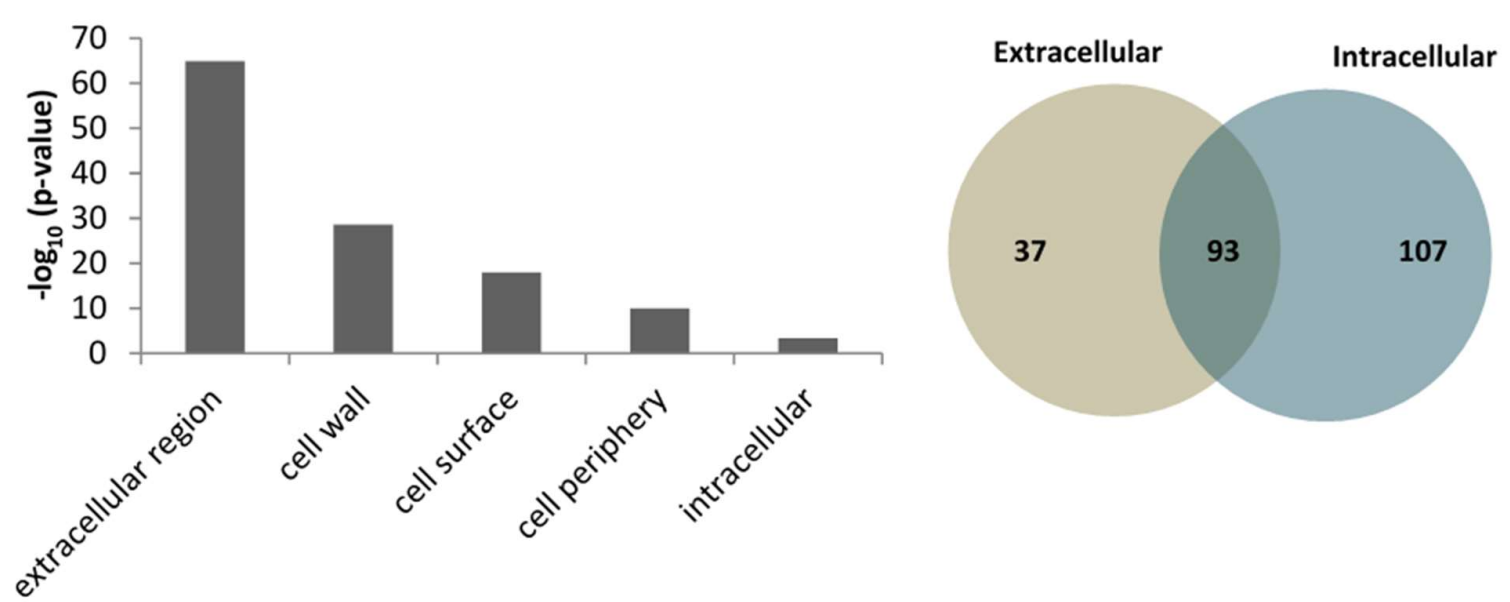

Figure 2. GO analysis of the proteins identified in both seccretome batches (S1 and S2) with at least 2 peptides. (A) GO enrichment in biological process of the secreted proteins. (B) GO enrichment in cellular component of the secreted proteins. (C) Venn diagram showing the number of proteins annotated as extracellular and/or intracellular locations. 


\subsection{Serologic responses to the C. albicans hyphal secretome in $n c I C, c I C$ and non-IC patients}

To characterize the IgG antibody-reactivity patterns to the C.albicans hyphal secretome, three different pools of serum samples from $12 \mathrm{ncIC}, 11 \mathrm{cIC}$ and 11 non-IC patients were compared. Serum IgG antibody levels to both $C$. albicans hyphal secretome batches (S1 and S2) were measured by indirect ELISA. ncIC and cIC patients had higher IgG antibody levels to the C. albicans hyphal secretome than non-IC patients (Figure 3A). Interestingly, cIC patients showed higher, but not statistically significant, serum IgG antibody levels to $C$. albicans hyphal secreted proteins than ncC patients. The mean IgG antibody titers against the $C$. albicans hyphal secretome were significantly higher in ncIC and CIC patients (14.5 and 16.5, respectively) than in non-IC patients (11.5, $p=0.01$; Figure 3B). In contrast, IgG antibody titers against $C$. albicans hyphal cytoplasmic extract were not significantly higher in ncIC and cIC patients when compared to non-IC patients $(p$ $=0.2$, Figure 3C).

These results prompted us to further analyze the serologic responses from the different patient groups using SERPA. Different immunoreactivity patterns were found in these groups (Figure 4). C.albicans hyphal secreted proteins showed higher immunoreactivity in ncIC and cIC patients than in non-IC patients, in line with ELISA data. Seven immunogenic secreted proteins from C. albicans hyphae involved in cell wall remodeling (Bg12), metabolism (Eno1, Glx3, Pgk1 and Tdh3), and host interaction (Pra1 and Sap5) were identified (Table 2 and Figure S3). Bgl2 and Glx3 were recognized by serum pools from ncIC and cIC patients but not from non-IC patients. Eno1, Pgk1, Pra1 were more immunoreactive with sera from ncIC and $\mathrm{CIC}$ patients than from non-IC patients. Sap5 was more immunoreactive in cIC patients than in ncIC and non-IC patients, in which showed similar immunoreactivity levels. Pra1 was the most immunoreactive protein (especially in cIC patients). Tdh3 was exclusively immunorecognized by sera from cIC patients.

High levels of immunoreactivity were observed in hyphal secreted proteins located on the upper-left high-molecular-weight (HMW)/acidic corner of the 2-D immunoblots, particularly when these were incubated with sera from ncIC and cIC patients. Four protein bands were excised from this zone of the 2-DE gel and identified by LC-MS/MS (Table 3 and Table S4). The majority of the identified proteins were associated with the cell wall (Tos1, Ecm33, Sim1, Sun41, Cht3 and Mp65) and the cell surface or extracellular medium (Rbt4 and Pra1). The theoretical molecular weights of the identified proteins were lower than those of this zone of the 2-DE gel (except for Cht3 and Scw11), which is in accordance with the high degree of glycosylation of many cell wall proteins. The more abundant identified proteins had at least one predicted glycosylation site (Table 3). 
A

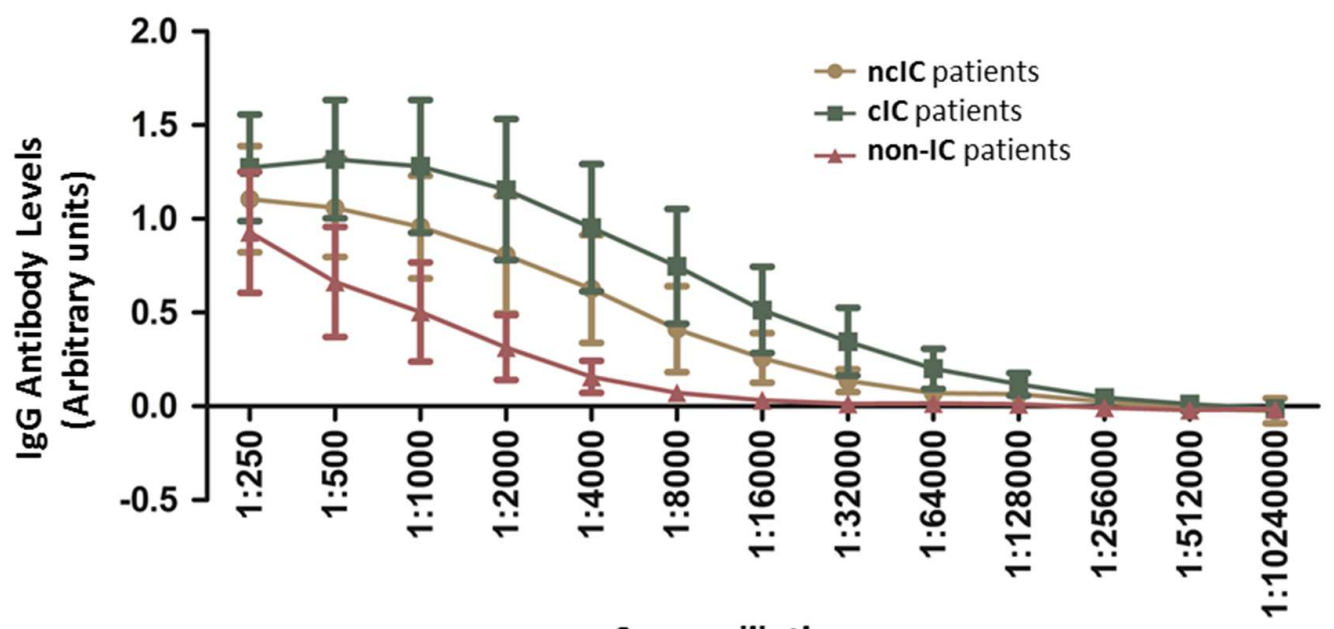

Serum dilutions

B

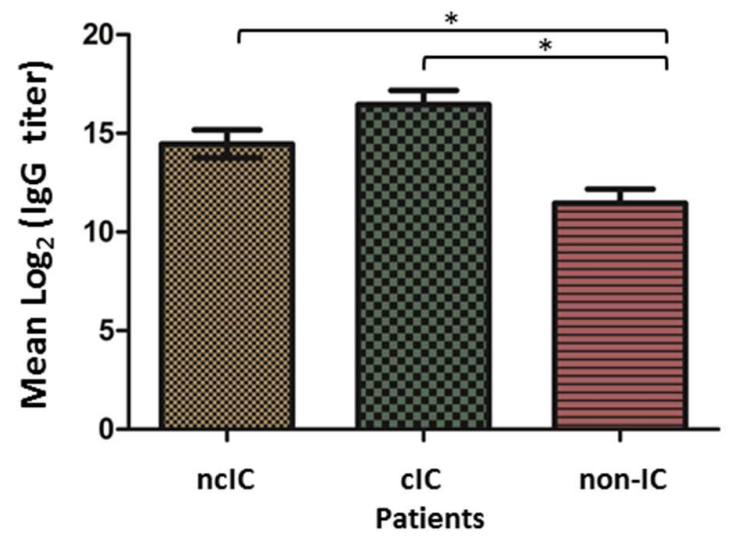

C

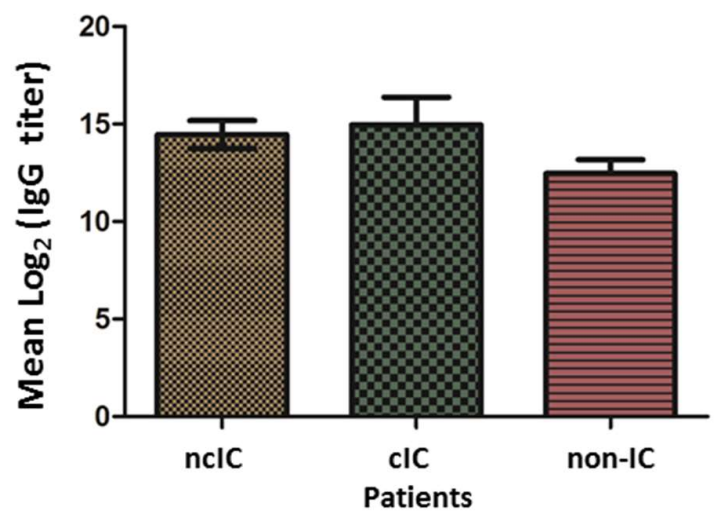

Figure 3. ELISA measurements of IgG antibodies against both C. albicans hyphal secretome batches (S1 and S2) using serum pools from ncIC, cIC and non-IC patients. (A) IgG levels against S1 and S2 in the three serum pools at different dilutions. (B) Serum titers of IgG antibodies against the $C$. albicans hyphal secretome in ncIC, cIC and non-IC patients. * $p$-value $<0.05$. (C) Serum titers of IgG antibodies against the $C$. albicans hyphal cytoplasmic proteome in ncIC, cIC and non-IC patients. 


\section{A Sypro Ruby-stained membranes}

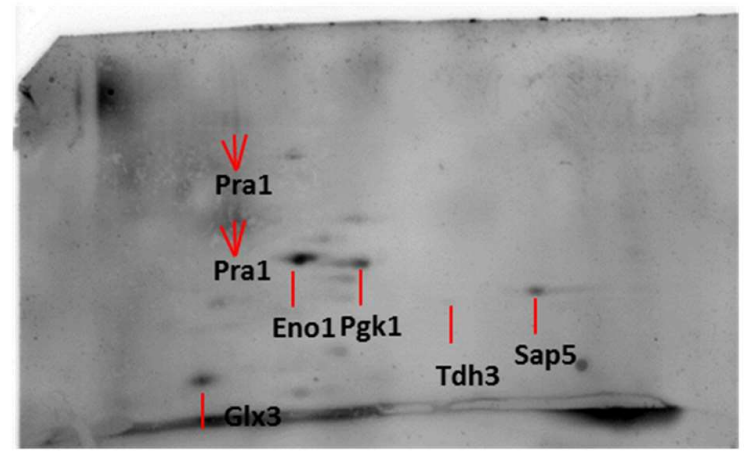

B

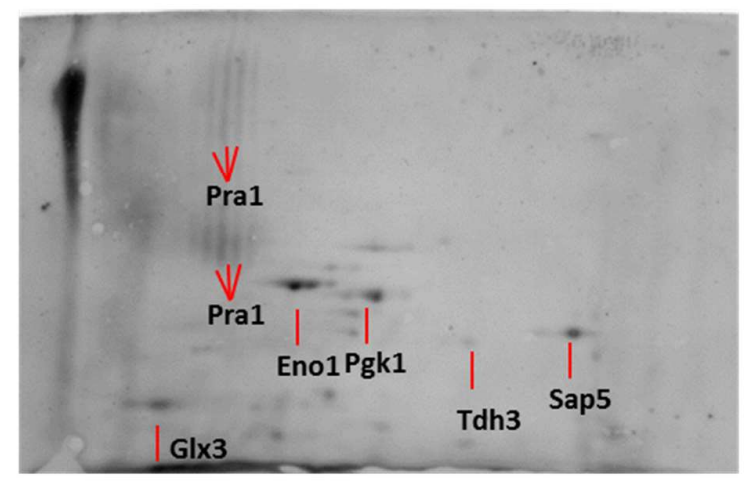

C

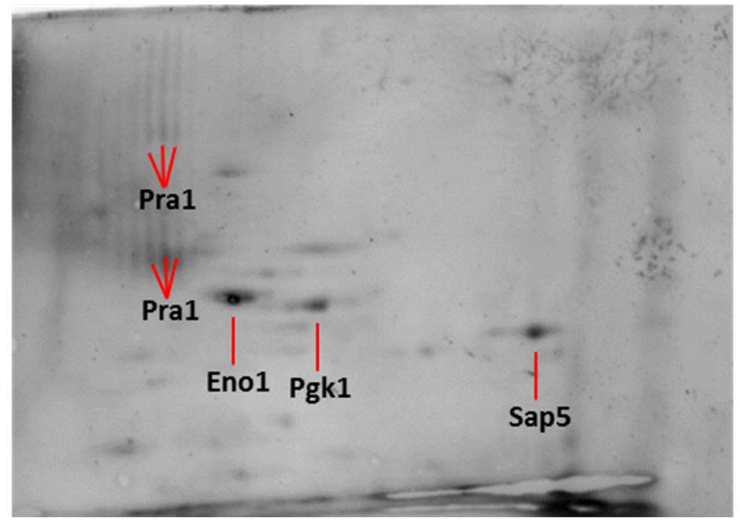

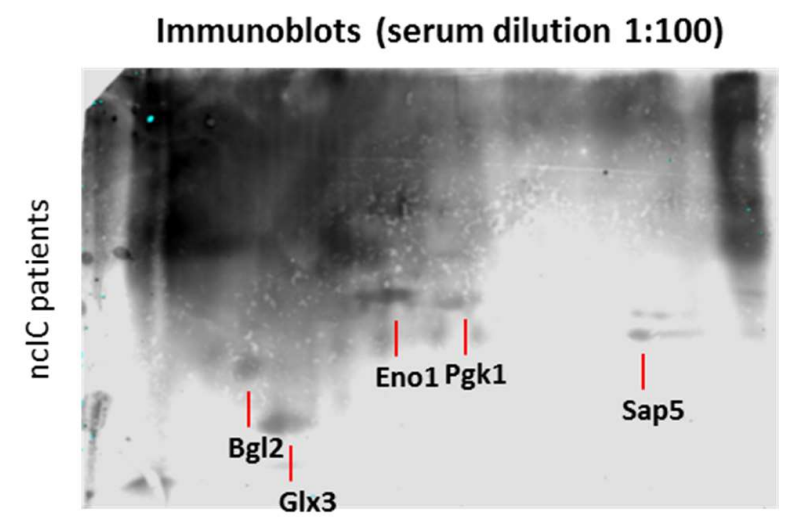

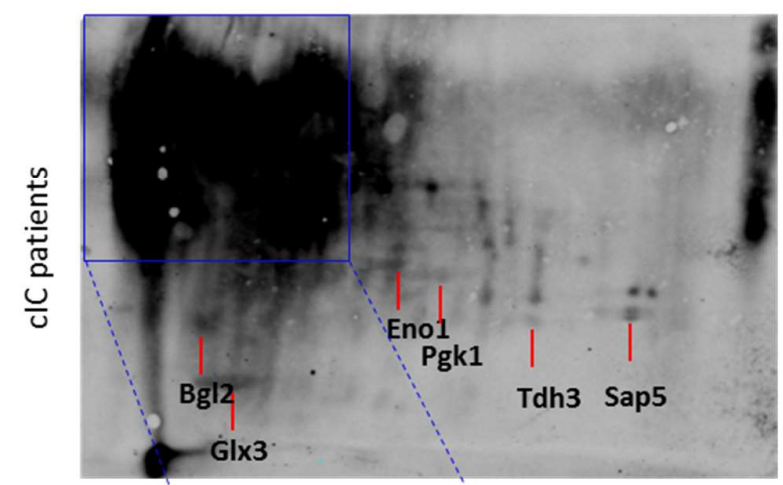

Serum dilution 1:500
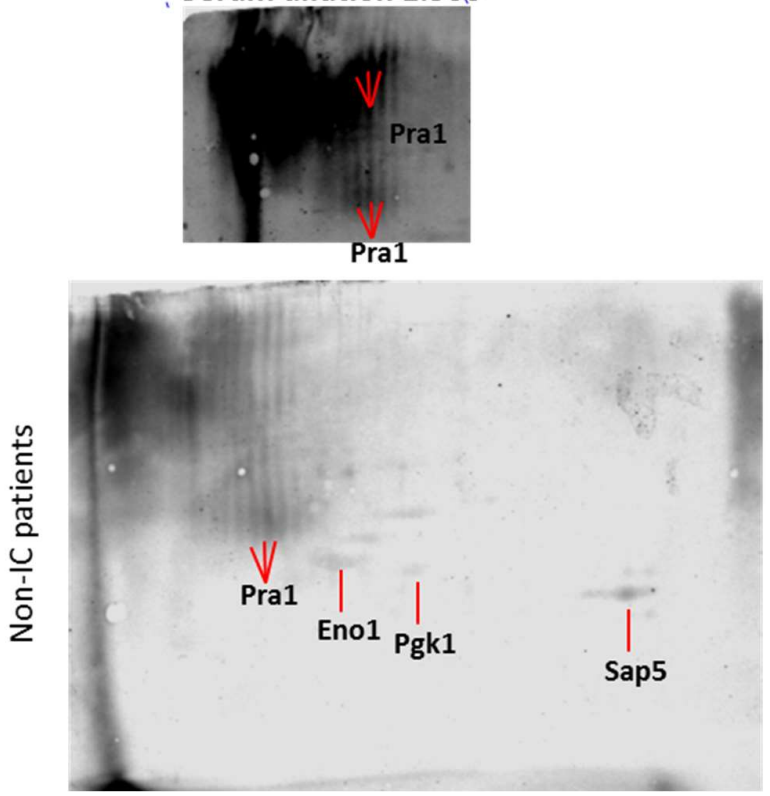

Figure 4. Comparison of serum IgG antibody reactivity profiles to the C. albicans hyphal secretome by SERPA. Representative Sypro Ruby-stained membranes (left) and 2-D immunoblots (right) using sera from (A) ncIC patients, (B) cIC patients, and (C) non-IC patients at a dilution of 1:100 are shown. In (B), it is also depicted a part of the 2-D immunoblot with a lower dilution of sera (1:500) where defined immunoreactive spots instead of the smear can be observed. The immunoreactive proteins identified by MALDI-TOF are labeled.

\section{Discussion}


4.1. The C. albicans hyphal secretome comprises proteins involved in interaction with host and immunogenic proteins

Lee medium was selected for $C$. albicans cell growth mainly due to the identification of more proteins with signal peptide than in the other medium assessed. This medium was previously used to induce hyphal morphology in C. albicans [44, 51, 52]. GO enrichment analysis revealed that the identified extracellular proteins were mainly involved in interaction with the host (such as pathogenesis, cellular response to oxidative stress, induction by symbiont of host defense response, and adhesion to the host). Among those, we identified proteins from the Sap family (Sap5, Sap4, Sap10 and Sap8), which are implicated in degradation of host proteins [53], Als1 and Xog1, which are involved in cell adherence and biofilm formation [54], and Ecm33, which is required for cell wall integrity, morphogenesis, virulence, as well as response to temperature, osmotic and oxidative stress in C. albicans [55-59].

Different proteins located at the cell wall were also identified, such as some GPIanchored (Ecm33, Pga4, Rhd3, Utr2) as well as non-covalently attached (Kre9, Bg12, Eng1, Mp65, Cht1, Cht2) cell wall proteins. The presence of cell wall proteins in the C. albicans secretome was previously noticed in other works $[32,60]$. This is consistent with the fact that some of them may be detached from the cell wall during cell growth, or fail to incorporate in the first place. Only $12 \%$ of the genes for the identified proteins encoded for signal peptide. However, several proteins were described as being located both intraand extracellularly, suggesting that a great number of proteins were secreted by noncanonical mechanisms. These proteins may be secreted inside EVs [37, 38]. When comparing the proteins identified in this study with those reported in EVs and EVs-free secretome from C. albicans [38], we observe that 16 proteins (Bgl2, Cht1, Cht3, Coi1, Cyp5, Ecm33, Eng1, Mp65, orf19.4952.1, Pga4, Phr2, Rbe1, Rhd3, Sim1, Utr2, and Xog1) were common to all conditions. Only 4 proteins (Asc1, Hex1, Sap10, and Sap8) were common between our secretome and the EV-free secretome described previously. Interestingly, other 16 proteins (Cyp1, Eft2, Eno1, Gpm1, Hsp70, Met6, Mnt1, Pdc11, Pgk1, Por1, Rho1, Sah1, Ssa2, Tal1, Tdh3, and Ykt6) were common only between EVs secretome [34] and the secretome described here. Some of the identified proteins are moonlighting proteins, such as Tdh3, which is a well-known housekeeping enzyme found also at the cell surface of C. albicans and to be immunogenic [61], or Eno1 and Eft2, which can bind serum proteins $[39,62]$, among others.

We found that 190 out of the 301 identified proteins were already described in earlier studies on the C. albicans hyphal secretome [32, 60, 63] (Table S5). Out of the 111 remaining identified proteins, 4 and 48 were already reported in a gel-based proteomic work [32], and in a recent study showing the comparison of the proteomic composition of planktonic and biofilm EVs from C. albicans (where the planktonic cells were in the hyphal form) [42], respectively (Figure S4). These observations suggest that several proteins identified in this study were secreted by non-conventional pathways of secretion [37, 38, 42]. These dissimilarities in the composition of the $C$. albicans hyphal secretome may be attributed to differences in cell growth media, time and temperature of incubation, and extraction protocol (Figure S1), as well as the type of mass spectrometers used for protein identification, among others, as pointed out previously [34]. With the MS technology evolving so quickly and its detection sensitivity increasing, more proteins can consequently be identified in the fungal secretomes. Some of the proteins identified in the hyphal secretome were previously described in the C.albicans surfome or surfaceome (such as Cip1, Cmd1, Egd1, Hnt1, Hsp12, Mdg1, orf19.5943.1, orf19.7196 and orf19.7368) [64-68] (Table S6). As these proteins are non-covalently attached to the cell surface, they may have detached during the experimental procedures of this study, or be located at the cell surface in their transition to the extracellular environment.

The proteomic analysis performed on the C. albicans hyphal secretome enabled the identification of 47 proteins previously characterized as immunogenic proteins (Table 4). Most of them did not have signal peptide and were annotated in the extra- and intracellular compartments. 
4.2. The C. albicans hyphal immunosecretome recognized by IgG antibodies differs between IC and non-IC patients

Serum IgG antibody levels to the C. albicans hyphal secretome were higher in ncIC and $\mathrm{CIC}$ patients than in non-IC patients, indicating that IC patients mounted stronger IgG antibody responses to $C$. albicans hyphal secreted proteins than non-IC patients. These results are in line with earlier studies [23, 27, 28, 47,69]. The slightly, but not significantly, higher immunoreactivity of this subproteome in cIC patients than in ncIC patients could be attributed, at least in part, to the easy access of $C$. albicans cells from the contaminated catheters to bloodstream in $\mathrm{CIC}$, as well as to the lower amount of $C$. albicans cells into the bloodstream in ncIC because IC was associated with candidemia (ncIC and cIC) and/or deep-seated candidiasis (ncIC), resulting in lower IgG antibody levels to the C. albicans hyphal secretome.

\subsection{IgG antibodies to Bgl2, Eno1, Pgk1, Glx3, Pra1, Sap5 and Tdh3 are IC diagnostic biomarker} candidates

We identified seven highly immunoreactive C. albicans secreted proteins (Bg12, Eno1, Glx3, Sap5, Pgk1, Pra1 and Tdh3). IgG antibody titers to Bg12, Eno1, Glx3 and Pgk1 enabled the discrimination of IC (ncIC and CIC) patients from non-IC patients, whereas IgG antibodies to Sap5, Pra1 and Tdh3 allowed the discrimination between cIC and nonIC patients, but not between ncIC and non-IC patients.

Bgl2 was identified by LC-MS/MS only at a lower ranking position, indicating a lower abundance than the other secreted proteins (Nr 55, NSAF 0.0045). At the same time Bgl2 elicited higher IgG antibody levels in both IC groups than in the control group, which did not show immunoreactivity to this secreted protein. Anti-Bgl2 IgG antibodies were previously reported as a biomarker candidate for IC diagnosis [23]. Bgl2 is a 1,3-betaglucosyltransferase localized in the cell wall active on $\beta-1,3$ glucan molecules, resulting in a $\beta$-1,3-glucan chain elongated with a $\beta-1,6$ glucan at the transfer site [70]. This protein also contributes to the delivery and accumulation of glucan for biofilm matrix building [71]. It was previously observed in the C. albicans yeast and hyphal secretomes [32, 38, 60, 63, 72].

Eno1 and Pgk1 were at the highest ranking positions (1 and 2 respectively), indicating that they are highly abundant in the extracellular medium of $C$. albicans hyphal cells, and triggered IgG antibody responses that also enabled the differentiation between IC and non-IC patients in line with previous studies [23, 27, 28, 69]. Eno1 is a multifunctional protein with key roles in the glycolytic pathway, colonization of mammalian intestinal epithelium [73], and binding to human plasminogen [39, 74]. Pathogens recruit the host plasminogen to increase their invasive capacity $[74,75]$. Pgk1 is also a moonlighting protein involved in the glycolysis and binding to plasminogen [76]. Both proteins have been found both in the cytoplasm and in the cell wall $[52,77]$.

Glx3 was detected by LC-MS/MS but it was not included in the list of identified proteins due to the statistical filters applied. However, it was also abundant in the preparative 2-DE gel. Interestingly, it was found to be immunoreactive in the IC groups, but it did not display immunoreactivity in the control group. Glx3 is a glyoxalase that converts methylglyoxal to D-lactate [78]. Most significantly, it is a very abundant protein in the biofilm extracellular matrix [79]. C. albicans glx3 $\Delta$ mutant showed impaired growth on media with glycerol. The mutant has impaired filamentation and biofilm formation [79]. In addition to being present in biofilm matrix, it has also been found in C. albicans yeast and hyphal secretomes [32]. Glx3 was previously described as an immunogenic protein recognized by sera from IC patients [24, 26-28, 69].

Sap5 is part of the large family of secreted aspartyl proteases, which are associated with C. albicans virulence. This protein was ranked as third in LC-MS/MS identification. Sap family play important roles in degradation of proteins, and formation of biofilms associated with bloodstream infections caused by C. albicans $[53,80]$. This protein has been found in the C. albicans hyphal secretome [32,60], and to be an immunogenic protein [81]. 
We observed no significant differences in their IgG antibody-reactivity levels between ncIC and non-IC patients, in keeping with an earlier study [81].

Pra1 is a cell-wall associated protein [54]. This hyphal secreted protein was ranked in twelfth position according to its NSAF and was found to be highly abundant in the preparative 2-DE gel with characteristics of glycosylation. We also observed that was more immunoreactive in cIC patients than in non-IC patients. However, their elicited IgG antibodies did not enable the clear differentiation between ncIC and non-IC patients. A monoclonal antibody directed towards Pra1 has shown to confer protection [82]. C. albicans secretes Pra1 to sequester zinc from host cells [35]. Furthermore, Pra1 binds and complexes the complement molecules C3 and blocks C3 conversion by the host C3 convertases, and blocks the C3a antifungal activity [83].

Tdh3 was ranked in the ninth position of abundance and it was also detectable in the preparative 2-DE gel. It has been found be immunogenic [24, 28, 48, 61], and located at the C. albicans cell wall proteomes $[52,61]$ and yeast and hyphal secretomes [32]. Although their IgG antibody-reactivity levels were low, these allowed the differentiation of cIC patients from non-IC patients, but not between ncIC and non-IC patients.

The area corresponding to the more acidic and higher molecular mass proteins on 2DE gels was also enriched for highly glycosylated proteins. In spite of being difficult to correlate the antigenicity levels to a specific identifiable protein due to the high background, many of the identified proteins in this area of the 2-DE gel were predicted at least with one bioinformatic tool to have one glycosylation site (Table 3) or described previously to be glycosylated. In particular, Mp65, Sun41, Cht3 and Ecm3 are proteins located at the cell surface, and previously described to be glycosylated [84-86]. Mp65 was also found to be more abundantly released in hyphal forms of $C$. albicans and to stimulate cell-mediated immune responses [87].

C. albicans glycosylated cell wall proteins are covalently attached to structural polysaccharides in two ways. Glycophosphatidylinositol (GPI)-anchored proteins, which are linked to $\beta$-1,6-glucan through a GPI remnant, and Pir proteins, which are directly linked to $\beta$-1,3-glucan [54]. Glycosylated proteins can carry different types of antigenic epitopes. Some oligosaccharides can also be antigenic. Another type is glycopeptide epitopes defined by antibodies which recognize specific oligosaccharide structures and adjacent amino acid residues. There are peptidic epitopes, which represent either relatively short sequences of the polypeptide chains or include amino acid residues brought into proximity due to the secondary structure of the proteins [88]. Recently, the role of glycosylation in the recognition of protein antigens by antibodies was studied. Luo and co-workers studied the immunoreactivity of Sap6 on the glycosylation status and found that anti-Sap6 antibody signal was drastically reduced after deglycosylation. Furthermore, they observed that Mp65 and other cell wall proteins identified in this upper-left HMW/acidic corner of 2-DE gels showed reduced antibody recognition by sera from candidemia patients after deglycosylation [32].

\section{Conclusions}

This study provides new insight into the C. albicans hyphal secretome and serological response to it in ncIC, cIC and non-IC patients. Higher IgG antibody levels to C. albicans hyphal secretome are mounted by cIC group than by ncIC group, as well as by both IC groups than by non-IC group. Our results have also highlighted that C. albicans hyphal secreted Bg12, Eno1, Glx3, Sap5, Pgk1, Pra1 and Tdh3 have immunogenic properties, and that serum IgG antibodies to C. albicans Bg12, Eno1, Pgk1 and Glx3 are diagnostic biomarker candidates for IC. Future studies should be aimed to validate these candidates in larger patient cohorts.

Supplementary Materials: The following are available online at www.mdpi.com/xxx/s1, Figure S1: Isolation of the C. albicans hyphal secretome in two different growth media, Figure S2: Coomassie blue-stained SDS-PAGE gel of the 10 C. albicans hyphal secretome samples isolated in Lee medium 
(pH 6.7), Figure S3: Coomassie blue-stained preparative 2-DE gel of the C. albicans hyphal secretome, Figure S4: Schematic Venn diagrams comparing C. albicans secreted proteins described here and in other studies, Table S1: Baseline characteristics of the patients included in this study, Table S2: C. albicans hyphal secreted proteins identified after cell growth in salt medium+GlcNac and Lee medium, Table S3: C. albicans hyphal secreted proteins identified with at least 2 peptides and present in both independent batches (S1 and S2), Table S4: C. albicans hyphal secreted proteins identified with at least 2 peptides in the left upper corner of the preparative 2-DE gel, Table S5: Comparison between proteins previously reported in the hyphal C. albicans secretome or biofilm EVs and our study, Table S6: C. albicans hyphal secreted proteins identified in our study that were previously described in surfome studies.

Author Contributions: Conceptualization, C.V., A.P., A. A.-G., L.M. and C.G.; methodology, C.V. and A.P.; formal analysis, C.V.; investigation, C.V. and A.P.; resources, E.G.-M., M.W. and O.B.; writing-original draft preparation, C.V.; writing-review and editing, A.P., O.B., L.M. and C.G.; supervision, A.P., L.M. and C.G.; funding acquisition, L.M. and C.G. All authors have read and agreed to the published version of the manuscript.

Funding: This research was funded by the Marie Curie Initial Training Network (FP7-PEOPLE2013-ITN ImResFun) to OB and CG, BIO2015-65147-R and RTI2018-094004-B-100 from Spanish Ministry of Economy and Competitiveness (MINECO), InGEMICS-CM B2017/BMD-3691 from the Community of Madrid, Spanish Network for the Research in Infectious Diseases (REIPI RD16/0016/0011) and PRB3 (PT17/0019/0012) from the ISCIII. InGEMICS-CM, REIPI and PRB3 are co-financed by European Development Regional Fund ERDF "A way to achieve Europe".

Institutional Review Board Statement: The study was conducted according to the guidelines of the Declaration of Helsinki, and approved by the Ethics Committee of University Medical Center Göttingen (UMG-17/9/08).

Informed Consent Statement: Informed consent was obtained from all subjects involved in the study.

Data Availability Statement: The mass spectrometry proteomics data have been deposited to the ProteomeXchange Consortium via the PRIDE partner repository with the dataset identifier PXD013933.

Acknowledgments: LC-MS/MS and MALDI-TOF-MS proteomics analyses were performed in Proteomics Facility of Complutense University of Madrid (UCM), member of ProteoRed-ISCIII network. These results are lined up with the Human Infectious Diseases HPP initiative from the Human Proteome Project (HID-HPP).

Conflicts of Interest: The authors declare no conflict of interest. The funders had no role in the design of the study; in the collection, analyses, or interpretation of data; in the writing of the manuscript, or in the decision to publish the results. 
Table 1. List of the identified proteins in both secretome batches (S1 and S2) with at least two peptides classified regarding their cellular location. ${ }^{a}$

\begin{tabular}{|c|c|c|}
\hline Cellular location & $\begin{array}{c}\text { No. of } \\
\text { identified } \\
\text { proteins }\end{array}$ & Protein names \\
\hline $\begin{array}{l}\text { Extracellular } \\
\text { region, cell surface, } \\
\text { cell wall, and cell } \\
\text { periphery }\end{array}$ & 37 & $\begin{array}{l}\text { Ade8, Als1, Bg12, Cht1, Cht3, Cip1, Coi1, Ece1, Ecm33, Gcy1, Grp2, Hex1, } \\
\text { Kre9, Mal2, Mdg1, Met15, Mp65, Nit3, Ofr1, Orf19.1394, Orf19.3053, } \\
\text { Orf19.6809, Orf19.6867, Orf19.7322, Pga12, Pga4, Pra1, Pst2, Rbe1, Rbp1, } \\
\text { Rhd3, Sah1, Sap10, Sap8, Slk19, Sol3, Xyl2 }\end{array}$ \\
\hline Intracellular region & 107 & $\begin{array}{l}\text { Ade17, Aha1, Ams1, Anb1, Arf2, Arg1, Arg3, Arg4, Aro2, Asc1, Bfr1, Bud7, } \\
\text { Cit1, Cmd1, Cpr6, Crm1, Cyc1, Dtd2, Ecm4, Egd1, Eif4e, Erg10, Erg20, Etr1, } \\
\text { Fbp1, Fum11, Gcv3, Grs1, Grx3, Het1, His1, Hom2, Hta3, Hxk2, Idh1, Kex1, } \\
\text { Krs1, Lat1, Lsc1, Lys21, Mca1, Mcr1, Mdh1, Mmd1, Mrf1, Mxr1, Npt1, Ntf2, } \\
\text { Orf19.1355, Orf19.1448.1, Orf19.1738.1, Orf19.1815, Orf19.2930, Orf19.3319, } \\
\text { Orf19.3681, Orf19.3932, Orf19.4150, Orf19.4382, Orf19.4898, Orf19.518, } \\
\text { Orf19.5322, Orf19.5943.1, Orf19.5961, Orf19.6559, Orf19.6596, Orf19.6701, } \\
\text { Orf19.6872, Orf19.7152, Orf19.7196, Orf19.7214, Orf19.7297, Orf19.7330, } \\
\text { Orf19.7368, Orf19.7404, Orf19.7531, Orf19.7578, Orf19.86, Orf19.904, Pol30, } \\
\text { Rdi1, Rnr21, Rpl10a, Rpl12, Rpl30, Rpp0, Rps12, Rps19a, Rps21b, Rps22a, } \\
\text { Sbp1, Sec14, Skp1, Sno1, Snz1, Sod2, Sod3, Sub2, Sui1, Tfs1, Thi4, Tif1, Tub1, } \\
\text { Tub2, Tup1, Uba1, Yhb1, Ykt6 }\end{array}$ \\
\hline Both locations & 93 & $\begin{array}{l}\text { Aat21, Abp1, Acb1, Aco1, Ahp1, Ape3, Atp1, Atp2, Bmh1, Cam1, Cat1, } \\
\text { Cdc19, Cdc3, Cof1, Cyp1, Cyp5, Eft2, Egd2, Emp24, Eng1, Eno1, Fba1, Fdh1, } \\
\text { Gdh3, Gnd1, Gpd2, Gph1, Gpm1, Gsp1, Hem13, Hsp12, Hsp70, Hsp90, } \\
\text { Ino1, Ipp1, Kel1, Leu2, Lpd1, Lsp1, Mdh1-1, Met6, Mir1, Mlc1, Mnt1, } \\
\text { Orf19.1085, Orf19.1862, Orf19.1946, Orf19.3915, Orf19.4395, Orf19.4597, } \\
\text { Orf19.5342, Pdc11, Pet9, Pfy1, Pgi1, Pgk1, Phr2, Pin3, Pmm1, Por1, Prx1, } \\
\text { Pst3, Rho1, Rib3, Rpl14, Rp16, Rps20, Sam2, Sap4, Sap5, Sec4, Sim1, Smt3, } \\
\text { Sod1, Spe3, Ssa2, Ssb1, Tal1, Tdh3, Tma19, Tpi1, Tpm2, Trr1, Trx1, Tsa1, } \\
\text { Ttr1, Ubi3, Ugp1, Utr2, Vps21, Xog1, Ynk1, Ypt1 }\end{array}$ \\
\hline
\end{tabular}

${ }^{a}$ CGD and its GO tool were used for this analysis. In bold, proteins that were previously described to be immunogenic in C. albicans $[23,24,26,32,81,89]$. Proteins highlighted in grey are those that have signal peptide. 
Table 2. Recognition patterns of C. albicans hyphal secreted proteins by serum pools from ncIC, cIC and non-IC patients.

\begin{tabular}{|c|c|c|c|c|c|c|c|c|c|c|c|}
\hline \multicolumn{9}{|c|}{ Immunoreactive $C$. albicans hyphal secreted proteins ${ }^{a}$} & \multicolumn{3}{|c|}{$\begin{array}{l}\text { IgG antibody- } \\
\text { reactivity levels }{ }^{b}\end{array}$} \\
\hline \multirow[b]{2}{*}{$\begin{array}{l}\text { Standard } \\
\text { name }\end{array}$} & \multirow[b]{2}{*}{$\begin{array}{l}\text { Systematic } \\
\text { name }\end{array}$} & \multirow[b]{2}{*}{ Description } & \multicolumn{3}{|c|}{ LC-MS/MS } & \multicolumn{3}{|c|}{ MALDI-TOF-MS } & \multirow[b]{2}{*}{ ncIc } & \multirow[b]{2}{*}{ cIC } & \multirow[b]{2}{*}{$\begin{array}{l}\text { Non- } \\
\text { IC }\end{array}$} \\
\hline & & & $\begin{array}{c}\text { No. of } \\
\text { peptides }\end{array}$ & $\begin{array}{l}\text { Ranking } \\
\text { according } \\
\text { to NSAF }\end{array}$ & NSAF & $\begin{array}{c}\text { No. of } \\
\text { matched/ } \\
\text { unmatched } \\
\text { peptides }\end{array}$ & $\begin{array}{c}\text { Mascot } \\
\text { score }\end{array}$ & $\begin{array}{c}\% \text { of } \\
\text { sequence } \\
\text { coverage }\end{array}$ & & & \\
\hline Bgl2 & C4_02250C_A & $\begin{array}{l}\text { Cell wall 1,3-beta- } \\
\text { glucosyltransferase }\end{array}$ & 8 & 55 & 0.004 & $10 / 58$ & 213 & 20 & +++ & +++ & - \\
\hline Eno1 & C1_08500C_A & Enolase & 30 & 1 & 0.08 & $9 / 61$ & 157 & 32 & ++++ & +++ & + \\
\hline Glx3 & C3_02610C_A & $\begin{array}{c}\text { Glutathione-independent } \\
\text { glyoxalase }\end{array}$ & NI & NI & NI & $12 / 56$ & 276 & 61 & +++ & +++ & - \\
\hline Pgk1 & C6_00750C_A & Phosphoglycerate kinase & 38 & 2 & 0.04 & $21 / 47$ & 460 & 48 & +++ & ++ & + \\
\hline \multirow[t]{6}{*}{$\operatorname{Pra}^{c}$} & C4_06980W_A & $\mathrm{pH}$ regulated antigen & 10 & 12 & 0.01 & $11 / 57$ & 240 & 29 & ND & +++++ & +++ \\
\hline & & & & & & $9 / 59$ & 218 & 16 & & & \\
\hline & & & & & & $10 / 58$ & 229 & 20 & & & \\
\hline & & & & & & $7 / 61$ & 75 & 8 & & & \\
\hline & & & & & & $7 / 60$ & 115 & 11 & & & \\
\hline & & & & & & $5 / 63$ & 96 & 7 & & & \\
\hline \multirow[t]{4}{*}{ Sap5 $5^{c}$} & C6_03030W_A & Secreted aspartyl proteinase & 26 & 3 & 0.03 & $14 / 54$ & 272 & 39 & ++ & +++ & ++ \\
\hline & & & & & & $28 / 43$ & 815 & 60 & & & \\
\hline & & & & & & $39 / 38$ & 1220 & 67 & & & \\
\hline & & & & & & $6 / 62$ & 60 & 18 & & & \\
\hline
\end{tabular}




\section{doi:10.20944/preprints202105.0752.v1}

Tdh3

C3_06870W_A

NAD-linked

glyceraldehyde-3-phosphate
27

$9 \quad 0.02$

$16 / 53$

140

${ }^{a}$ Standard name, systematic name and description of the proteins are according to CGD.

${ }^{b}$ From no (-) or less (+) to more (+++++) immunoreactivity. ND denotes that protein spot immunoreactivity was not possible to determine.

${ }^{c}$ Proteins that were identified in different spots of the preparative 2-DE gel. NI means that this protein was identified by LC-MS/MS but it did not pass the statistical filters. 
Table 3. The more abundant proteins identified by LC-MS/MS in the left upper corner of a preparative 2-DE gel of the C. albicans hyphal secretome. ${ }^{a}$

\begin{tabular}{|c|c|c|c|c|c|c|c|}
\hline $\begin{array}{l}\text { Systematic } \\
\text { name }\end{array}$ & $\begin{array}{l}\text { Standard } \\
\text { name }\end{array}$ & Description & $\begin{array}{l}\text { NetNGlyc } \\
1.0 \text { server } \\
\text { prediction }\end{array}$ & $\begin{array}{l}\text { NetNGlyc } \\
4.0 \text { server } \\
\text { prediction }\end{array}$ & NSAF & $\begin{array}{c}\text { No. } \\
\text { peptides }\end{array}$ & $\mathbf{M r}$ \\
\hline C1_07030C_A & Rbt4 & Pry family protein & no & yes & 0.19 & 11 & 37.4 \\
\hline C2_10030C_A & Mp65 & $\begin{array}{c}\text { Cell surface } \\
\text { mannoprotein }\end{array}$ & no & yes & 0.15 & 13 & 39.3 \\
\hline C6_00820W_A & Sun41 & $\begin{array}{l}\text { Cell wall glycosidase } \\
\text { Protein similar to alpha }\end{array}$ & yes & yes & 0.12 & 11 & 43.7 \\
\hline C3_01550C_A & Tos1 & $\begin{array}{l}\text { agglutinin anchor } \\
\text { subunit }\end{array}$ & no & yes & 0.10 & 15 & 49.4 \\
\hline C1_03190C_A & Ecm 33 & $\begin{array}{l}\text { GPI-anchored cell wall } \\
\text { protein }\end{array}$ & yes & yes & 0.03 & 6 & 43.5 \\
\hline CR_10110W_A & Cht3 & Major chitinase & no & yes & 0.03 & 7 & 60.0 \\
\hline C4_06980W_A & Pra1 & $\begin{array}{l}\text { Cell surface protein that } \\
\text { sequesters zinc from host } \\
\text { tissue }\end{array}$ & yes & yes & 0.02 & 7 & 33.1 \\
\hline C3_02610C_A & Glx3 & $\begin{array}{l}\text { Glutathione-independent } \\
\text { glyoxalase }\end{array}$ & yes & no & 0.02 & 12 & 25.8 \\
\hline C1_13940W_A & Sim1 & Adhesin-like protein & yes & yes & 0.01 & 9 & 39.4 \\
\hline C5_04110W_A & Scw11 & Cell wall protein & yes & yes & 0.01 & 10 & 54.4 \\
\hline
\end{tabular}

${ }^{a}$ Here are presented only the more abundant proteins (NSAF higher than 0.01). 
Table 4. LC-MS/MS-identified proteins that have shown to have immunogenic propierties in previous studies.

\begin{tabular}{|c|c|c|c|c|c|}
\hline $\begin{array}{l}\text { Systematic } \\
\text { name }^{a}\end{array}$ & $\begin{array}{c}\text { Standard } \\
\text { name } \\
\end{array}$ & Description $^{a}$ & $\begin{array}{c}\text { Cell } \\
\text { localization }^{b}\end{array}$ & $\begin{array}{c}\text { Signal } \\
\text { peptide }^{a}\end{array}$ & References $^{c}$ \\
\hline CR_08210C_A & Aco1 & Aconitase & Shared & No & {$[24,90]$} \\
\hline CR_04090C_A & Ade17 & $\begin{array}{l}\text { 5-Aminoimidazole-4- } \\
\text { carboxamide ribotide } \\
\text { transformylase }\end{array}$ & Intracellular & No & {$[24]$} \\
\hline C6_03700W_A & Als1 & Cell-surface adhesin & Extracellular & yes & {$[81]$} \\
\hline C7_01250W_A & Asc1 & $\begin{array}{l}\text { 40S ribosomal subunit similar to } \\
\text { G-beta subunits }\end{array}$ & Intracellular & No & {$[24]$} \\
\hline C1_04610W_A & Atp1 & ATP synthase alpha subunit & Shared & No & {$[24]$} \\
\hline C4_00270W_A & Atp2 & $\begin{array}{l}\text { F1 beta subunit of F1F0 ATPase } \\
\text { complex }\end{array}$ & Shared & No & {$[24]$} \\
\hline C4_02250C_A & Bgl2 & $\begin{array}{l}\text { Cell wall 1,3-beta- } \\
\text { glucosyltransferase }\end{array}$ & Extracellular & Yes & {$[23]$} \\
\hline C2_05460W_A & Cdc19 & $\begin{array}{c}\text { Pyruvate kinase at yeast cell } \\
\text { surface }\end{array}$ & Shared & No & {$[90]$} \\
\hline C4_03470C_A & Ece1 & Extent of cell elongation protein & Extracellular & yes & {$[81]$} \\
\hline C1_03190C_A & Ecm33 & GPI-anchored cell wall protein & Extracellular & yes & {$[81]$} \\
\hline C2_03100W_A & Eft2 & Elongation factor 2 & Shared & No & {$[90]$} \\
\hline C1_08500C_A & Eno1 & Enolase & Shared & No & {$[48,69,89]$} \\
\hline C4_01750C_A & Fba1 & Fructose-bisphosphate aldolase & Shared & No & {$[24]$} \\
\hline C1_13860C_A & Gnd1 & $\begin{array}{l}\text { 6-phosphogluconate } \\
\text { dehydrogenase }\end{array}$ & Shared & No & {$[28]$} \\
\hline C2_03270W_A & Gpm1 & Phosphoglycerate mutase & Shared & No & {$[24,90]$} \\
\hline C5_02860C_A & Grp2 & $\begin{array}{l}\text { NAD }(\mathrm{H}) \text {-linked methylglyoxal } \\
\text { oxidoreductase involved in } \\
\text { regulation of methylglyoxal and } \\
\text { pyruvate levels }\end{array}$ & Extracellular & No & {$[24]$} \\
\hline C3_04060C_A & Hem13 & $\begin{array}{c}\text { Coproporphyrinogen III } \\
\text { oxidase }\end{array}$ & Shared & No & {$[24]$} \\
\hline C1_13480W_A & Hsp70 & Putative Hsp70 chaperone & Shared & No & {$[24,89]$} \\
\hline C7_02030W_A & Hsp90 & Essential chaperone & Shared & No & {$[24,89]$} \\
\hline CR_04510W_A & Hxk2 & Hexokinase II & Intracellular & No & {$[24]$} \\
\hline CR_10100C_A & Ino1 & Inositol-1-phosphate synthase & Shared & No & {$[24]$} \\
\hline C2_08810C_A & Ipp1 & $\begin{array}{l}\text { Putative inorganic } \\
\text { pyrophosphatase }\end{array}$ & Shared & No & {$[24]$} \\
\hline CR_00540C_A & Mdh1 & $\begin{array}{c}\text { Mitochondrial malate } \\
\text { dehydrogenase }\end{array}$ & Intracellular & Yes & {$[24]$} \\
\hline C4_01900C_A & Mdh1-1 & $\begin{array}{c}\text { Predicted malate } \\
\text { dehydrogenase precursor }\end{array}$ & Shared & No & \\
\hline
\end{tabular}




\begin{tabular}{|c|c|c|c|c|c|}
\hline CR_01620C_A & Met6 & $5-$ & Shared & No & {$[47,90]$} \\
\hline & & $\begin{array}{c}\text { methyltetrahydropteroyltriglut } \\
\text { amate-homocysteine } \\
\text { methyltransferase }\end{array}$ & & & \\
\hline C2_10030C_A & Mp65 & Cell surface mannoprotein & Extracellular & Yes & {$[84,91]$} \\
\hline C1_06100C_A & Msi3 & Essential HSP70 family protein & Intracellular & No & \\
\hline C7_03860W_A & orf19.7196 & Putative vacuolar protease & Intracellular & Yes & {$[32]$} \\
\hline C1_14060W_A & orf19.7214 & Glucan 1,3-beta-glucosidase & Intracellular & No & {$[81]$} \\
\hline C4_06570C_A & Pdc11 & Pyruvate decarboxylase & Shared & No & {$[24]$} \\
\hline C5_05390C_A & Pga4 & $\begin{array}{c}\text { GPI-anchored cell surface } \\
\text { protein }\end{array}$ & Extracellular & Yes & {$[81]$} \\
\hline CR_06340C_A & Pgi1 & Glucose-6-phosphate isomerase & Shared & No & {$[24]$} \\
\hline C6_00750C_A & Pgk1 & Phosphoglycerate kinase & Shared & No & {$[48,89]$} \\
\hline C1_04100C_A & Por1 & $\begin{array}{c}\text { Mitochondrial outer membrane } \\
\text { porin }\end{array}$ & Shared & No & {$[24]$} \\
\hline C4_06980W_A & Pra1 & $\mathrm{pH}$ regulated antigen & Extracellular & Yes & {$[81,82]$} \\
\hline C7_02810W_A & $\operatorname{Prx1}$ & Thioredoxin peroxidase & Shared & No & {$[32]$} \\
\hline C5_04270C_A & Sah1 & $\begin{array}{c}\text { S-adenosyl-L-homocysteine } \\
\text { hydrolase }\end{array}$ & Extracellular & No & {$[24]$} \\
\hline C3_07310C_A & Slk19 & $\begin{array}{c}\text { Alkaline-induced protein of } \\
\text { plasma membrane }\end{array}$ & Extracellular & no & {$[81]$} \\
\hline C1_04300C_A & Ssa2 & HSP70 family chaperone & Shared & No & {$[24,81]$} \\
\hline CR_08090W_A & Ssb1 & $\begin{array}{c}\text { HSP70 family heat shock } \\
\text { protein }\end{array}$ & Shared & No & {$[24,31]$} \\
\hline CR_03720W_A & Tal1 & Transaldolase & Shared & No & {$[32]$} \\
\hline C3_06870W_A & Tdh3 & $\begin{array}{c}\text { NAD-linked glyceraldehyde-3- } \\
\text { phosphate dehydrogenase }\end{array}$ & Shared & No & {$[24,48,61]$} \\
\hline C1_01350C_A & Tif & Translation initiation factor & Intracellular & No & {$[24]$} \\
\hline C3_07440W_A & Tpi1 & Triose-phosphate isomerase & Shared & No & {$[24,31]$} \\
\hline C3_06180C_A & Tsa1 & $\begin{array}{c}\text { TSA/alkyl hydroperoxide } \\
\text { peroxidase C (AhPC) family } \\
\text { protein }\end{array}$ & Shared & No & {$[26]$} \\
\hline C3_01730C_A & Utr2 & $\begin{array}{l}\text { Putative GPI anchored cell wall } \\
\text { glycosidase }\end{array}$ & Extracellular & yes & {$[81]$} \\
\hline C1_02990C_A & Xog1 & Exo-1,3-beta-glucanase & Shared & Yes & [81] \\
\hline
\end{tabular}

${ }^{a}$ Names, description and prediction of signal peptide according to CGD

${ }^{b}$ Localization according to GO enrichment performed in CGD. "Shared" means that the protein was described intra- and extracellularly. "Extracellular" embraces extracellular region, cell surface, cell wall and cell periphery.

${ }^{c}$ Previous studies where these proteins were shown to have immunogenic propierties. 


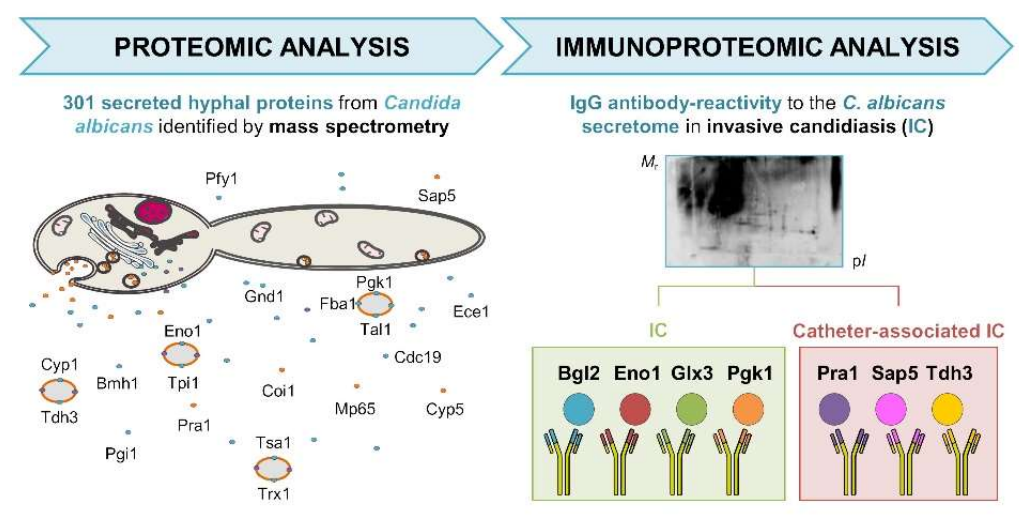

\section{Graphical abstract}




\section{References}

1. Sudbery P, Gow N, Berman J: The distinct morphogenic states of Candida albicans. Trends Microbiol 2004, 12(7):317-324.

2. Hofs S, Mogavero S, Hube B: Interaction of Candida albicans with host cells: virulence factors, host defense, escape strategies, and the microbiota. Journal of Microbiology 2016, 54(3):149-169.

3. Gow NA, Hube B: Importance of the Candida albicans cell wall during commensalism and infection. Current opinion in microbiology 2012, 15(4):406-412.

4. Wilson D, Naglik JR, Hube B: The missing link between Candida albicans hyphal morphogenesis and host cell damage. Plos Pathog 2016, 12(10).

5. Pappas PG, Lionakis MS, Arendrup MC, Ostrosky-Zeichner L, Kullberg BJ: Invasive candidiasis. Nature Reviews Disease Primers 2018, 4:18026.

6. Kullberg BJ, Arendrup MC: Invasive candidiasis. N Engl J Med 2015, 373(1):1445-1456.

7. Pitarch A, Nombela C, Gil C: Diagnosis of invasive candidiasis: From gold standard methods to promising leading-edge technologies. Current Topics in Medicinal Chemistry 2018, 18(16):1375-1392.

8. Nucci M, Anaissie E: Revisiting the source of candidemia: skin or gut? Clinical Infectious Diseases 2001, 33(12):1959-1967.

9. Phua AI, Hon KY, Holt A, O'Callaghan M, Bihari S: Candida catheter-related bloodstream infection in patients on home parenteral nutrition - Rates, risk factors, outcomes, and management. Clinical Nutrition ESPEN 2019, 31:1-9.

10. Magill SS, Edwards JR, Bamberg W, Beldavs ZG, Dumyati G, Kainer MA, Lynfield R, Maloney M, McAllister-Hollod L, Nadle J et al: Multistate point-prevalence survey of health care-associated infections. N Engl J Med 2014, 370(13):1198-1208.

11. Chaves F, Garnacho-Montero J, Del Pozo JL, Bouza E, Capdevila JA, de Cueto M, Dominguez MA, Esteban J, FernandezHidalgo N, Fernandez Sampedro M et al: Diagnosis and treatment of catheter-related bloodstream infection: Clinical guidelines of the Spanish Society of Infectious Diseases and Clinical Microbiology and (SEIMC) and the Spanish Society of Spanish Society of Intensive and Critical Care Medicine and Coronary Units (SEMICYUC). Medicina Intensiva 2018, 42(1):5-36.

12. Clancy CJ, Nguyen MH: Finding the "missing 50\%" of invasive candidiasis: how nonculture diagnostics will improve understanding of disease spectrum and transform patient care. Clinical Infectious Diseases 2013, 56(9):1284-1292.

13. Posch W, Heimdorfer D, Wilflingseder D, Lass-Florl C: Invasive candidiasis: future directions in non-culture based diagnosis. Expert Review of Anti-infective Therapy 2017, 15(9):829-838.

14. Pfaller MA, Castanheira M: Nosocomial candidiasis: Antifungal stewardship and the importance of rapid diagnosis. Med Mycol 2016, 54(1):1-22.

15. Clancy CJ, Nguyen MH: T2 magnetic resonance for the diagnosis of bloodstream infections: charting a path forward. Journal of Antimicrobial Chemotherapy 2018, 73(suppl_4):iv2-iv5.

16. Mylonakis E, Clancy CJ, Ostrosky-Zeichner L, Garey KW, Alangaden GJ, Vazquez JA, Groeger JS, Judson MA, Vinagre YM, Heard SO et al: T2 magnetic resonance assay for the rapid diagnosis of candidemia in whole blood: a clinical trial. Clinical Infectious Diseases 2015, 60(6):892-899.

17. Neely LA, Audeh M, Phung NA, Min M, Suchocki A, Plourde D, Blanco M, Demas V, Skewis LR, Anagnostou T et al: T2 magnetic resonance enables nanoparticle-mediated rapid detection of candidemia in whole blood. Science Translational Medicine 2013, 5(182):182ra154.

18. Krah A, Jungblut PR: Immunoproteomics. Methods Mol Med 2004, 94:19-32.

19. Dea-Ayuela MA, Ubeira FM, Pitarch A, Gil C, Martinez-Fernandez AR, Bolas F: A comparison of antigenic peptides in muscle larvae of several Trichinella species by two-dimensional Western-blot analysis with monoclonal antibodies. Parasite 2001, 8(2 Suppl):S117-S119.

20. Jungblut PR, Bumann D: Immunoproteome of Helicobacter pylori. Methods Enzymol 2002, 358:307-316.

21. Pedersen SK, Sloane AJ, Prasad SS, Sebastian LT, Lindner RA, Hsu M, Robinson M, Bye PT, Weinberger RP, Harry JL: An immunoproteomic approach for identification of clinical biomarkers for monitoring disease: application to cystic fibrosis. Mol Cell Proteomics 2005, 4(8):1052-1060. 
22. Thomas DP, Pitarch A, Monteoliva L, Gil C, Lopez-Ribot JL: Proteomics to study Candida albicans biology and pathogenicity. Infect Disord Drug Targets 2006, 6(4):335-341.

23. Pitarch A, Jimenez A, Nombela C, Gil C: Decoding serological response to Candida cell wall immunome into novel diagnostic, prognostic, and therapeutic candidates for systemic candidiasis by proteomic and bioinformatic analyses. Mol Cell Proteomics 2006, 5(1):79-96.

24. Pitarch A, Abian J, Carrascal M, Sanchez M, Nombela C, Gil C: Proteomics-based identification of novel Candida albicans antigens for diagnosis of systemic candidiasis in patients with underlying hematological malignancies. Proteomics 2004, 4(10):3084-3106.

25. Pitarch A, Nombela C, Gil C: Contributions of proteomics to diagnosis, treatment, and prevention of candidiasis. Methods Biochem Anal 2006, 49:331-361.

26. Pitarch A, Nombela C, Gil C: Prediction of the clinical outcome in invasive candidiasis patients based on molecular fingerprints of five anti-Candida antibodies in serum. Mol Cell Proteomics 2011, 10(1):M110 004010.

27. Pitarch A, Nombela C, Gil C: Serum antibody signature directed against Candida albicans Hsp90 and enolase detects invasive candidiasis in non-neutropenic patients. J Proteome Res 2014, 13(11):5165-5184.

28. Pitarch A, Nombela C, Gil C: Seroprofiling at the Candida albicans protein species level unveils an accurate molecular discriminator for candidemia. J Proteomics 2016, 134:144-162.

29. Huertas B, Prieto D, Pitarch A, Gil C, Pla J, Diez-Orejas R: Serum antibody profile during colonization of the mouse gut by Candida albicans: Relevance for protection during systemic infection. J Proteome Res 2017, 16(1):335-345.

30. Pitarch A, Nombela C, Gil C: The Candida immunome as a mine for clinical biomarker development for invasive candidiasis: From biomarker discovery to assay validation. In: San-Blas G, Calderone R, editors Pathogenic fungi: Insights in molecular biology Wymondham: Caister Academic Press pp 103-142 2008.

31. Pitarch A, Diez-Orejas R, Molero G, Pardo M, Sanchez M, Gil C, Nombela C: Analysis of the serologic response to systemic Candida albicans infection in a murine model. Proteomics 2001, 1(4):550-559.

32. Luo T, Kruger T, Knupfer U, Kasper L, Wielsch N, Hube B, Kortgen A, Bauer M, Giamarellos-Bourboulis EJ, Dimopoulos G et al: Immunoproteomic analysis of antibody responses to extracellular proteins of Candida albicans revealing the importance of glycosylation for antigen recognition. J Proteome Res 2016, 15(8):2394-2406.

33. Klis FM, Brul S: Adaptations of the secretome of Candida albicans in response to host-related environmental conditions. Eukaryot Cell 2015, 14(12):1165-1172.

34. Gil-Bona A, Amador-Garcia A, Gil C, Monteoliva L: The external face of Candida albicans: A proteomic view of the cell surface and the extracellular environment. J Proteomics 2018, 180:70-79.

35. Citiulo F, Jacobsen ID, Miramon P, Schild L, Brunke S, Zipfel P, Brock M, Hube B, Wilson D: Candida albicans scavenges host zinc via Pra1 during endothelial invasion. Plos Pathog 2012, 8(6):e1002777.

36. Wu H, Downs D, Ghosh K, Ghosh AK, Staib P, Monod M, Tang J: Candida albicans secreted aspartic proteases 4-6 induce apoptosis of epithelial cells by a novel Trojan horse mechanism. Faseb J 2013, 27(6):2132-2144.

37. Nombela C, Gil C, Chaffin WL: Non-conventional protein secretion in yeast. Trends Microbiol 2006, 14(1):15-21.

38. Gil-Bona A, Llama-Palacios A, Parra CM, Vivanco F, Nombela C, Monteoliva L, Gil C: Proteomics unravels extracellular vesicles as carriers of classical cytoplasmic proteins in Candida albicans. J Proteome Res 2015, 14(1):142-153.

39. Satala D, Satala G, Karkowska-Kuleta J, Bukowski M, Kluza A, Rapala-Kozik M, Kozik A: Structural insights into the interactions of candidal enolase with human vitronectin, fibronectin and plasminogen. Int J Mol Sci 2020, 21(21).

40. Parnanen P, Sorsa T, Tervahartiala T, Nikula-Ijas P: Isolation, characterization and regulation of moonlighting proteases from Candida glabrata cell wall. Microb Pathog 2020, 149:104547.

41. Nimrichter L, de Souza MM, Del Poeta M, Nosanchuk JD, Joffe L, Tavares Pde M, Rodrigues ML: Extracellular vesicleassociated transitory cell wall components and their impact on the interaction of fungi with host cells. Front Microbiol 2016, 7:1034. 
42. Zarnowski R, Sanchez H, Covelli AS, Dominguez E, Jaromin A, Berhardt J, Heiss C, Azadi P, Mitchell A, Andes DR: Candida albicans biofilm-induced vesicles confer drug resistance through matrix biogenesis. PLoS Biology 2018, 16(10):e2006872.

43. Yin QY: Exploring the fungal wall proteome by mass spectrometry. University of Amsterdam; 2008.

44. Lee KL, Buckley HR, Campbell CC: An amino acid liquid synthetic medium for the development of mycelial and yeast forms of Candida albicans. Sabouraudia 1975, 13(2):148-153.

45. Pitarch A, Nombela C, Gil C: Top-down characterization data on the speciation of the Candida albicans immunome in candidemia. Data Brief 2016, 6:257-261.

46. Pitarch A, Nombela C, Gil C: Identification of the Candida albicans immunome during systemic infection by mass spectrometry. Methods Mol Biol 2009, 470:187-235.

47. Pitarch A, Nombela C, Gil C: Reliability of antibodies to Candida methionine synthase for diagnosis, prognosis and risk stratification in systemic candidiasis: A generic strategy for the prototype development phase of proteomic markers. Proteomics Clin Appl 2007, 1(10):1221-1242.

48. Pitarch A, Pardo M, Jimenez A, Pla J, Gil C, Sanchez M, Nombela C: Two-dimensional gel electrophoresis as analytical tool for identifying Candida albicans immunogenic proteins. Electrophoresis 1999, 20(4-5):1001-1010.

49. Pitarch A, Nombela C, Gil C: Proteomic profiling of serologic response to Candida albicans during host-commensal and hostpathogen interactions. Methods Mol Biol 2009, 470:369-411.

50. Zybailov B, Mosley AL, Sardiu ME, Coleman MK, Florens L, Washburn MP: Statistical analysis of membrane proteome expression changes in Saccharomyces cerevisiae. J Proteome Res 2006, 5(9):2339-2347.

51. Nantel A, Dignard D, Bachewich C, Harcus D, Marcil A, Bouin AP, Sensen CW, Hogues H, van het Hoog M, Gordon P et al: Transcription profiling of Candida albicans cells undergoing the yeast-to-hyphal transition. Molecular Biology of the Cell 2002, 13(10):3452-3465.

52. Pitarch A, Sanchez M, Nombela C, Gil C: Sequential fractionation and two-dimensional gel analysis unravels the complexity of the dimorphic fungus Candida albicans cell wall proteome. Mol Cell Proteomics 2002, 1(12):967-982.

53. Naglik JR, Challacombe SJ, Hube B: Candida albicans secreted aspartyl proteinases in virulence and pathogenesis. Microbiology and Molecular Biology Reviews 2003, 67(3):400-428, table of contents.

54. Chaffin WL: Candida albicans cell wall proteins. Microbiology and Molecular Biology Reviews 2008, 72(3):495-544.

55. Martinez-Lopez R, Monteoliva L, Diez-Orejas R, Nombela C, Gil C: The GPI-anchored protein CaEcm33p is required for cell wall integrity, morphogenesis and virulence in Candida albicans. Microbiology 2004, 150(Pt 10):3341-3354.

56. Gil-Bona A, Reales-Calderon JA, Parra-Giraldo CM, Martinez-Lopez R, Monteoliva L, Gil C: The cell wall protein Ecm33 of Candida albicans is involved in chronological life span, morphogenesis, cell wall regeneration, stress tolerance, and host-cell interaction. Front Microbiol 2016, 7:64.

57. Gil-Bona A, Monteoliva L, Gil C: Global proteomic profiling of the secretome of Candida albicans ecm33 cell wall mutant reveals the involvement of Ecm33 in Sap2 secretion. J Proteome Res 2015, 14(10):4270-4281.

58. Martinez-Lopez R, Park H, Myers CL, Gil C, Filler SG: Candida albicans Ecm33p is important for normal cell wall architecture and interactions with host cells. Eukaryot Cell 2006, 5(1):140-147.

59. Monteoliva L, Martinez-Lopez R, Pitarch A, Hernaez ML, Serna A, Nombela C, Albar JP, Gil C: Quantitative proteome and acidic subproteome profiling of Candida albicans yeast-to-hypha transition. J Proteome Res 2011, 10(2):502-517.

60. Sorgo AG, Heilmann CJ, Dekker HL, Brul S, de Koster CG, Klis FM: Mass spectrometric analysis of the secretome of Candida albicans. Yeast 2010, 27(8):661-672.

61. Gil-Navarro I, Gil ML, Casanova M, O'Connor JE, Martinez JP, Gozalbo D: The glycolytic enzyme glyceraldehyde-3-phosphate dehydrogenase of Candida albicans is a surface antigen. J Bacteriol 1997, 179(16):4992-4999.

62. Karkowska-Kuleta J, Kozik A: Moonlighting proteins as virulence factors of pathogenic fungi, parasitic protozoa and multicellular parasites. Molecular Oral Microbiology 2014, 29(6):270-283. 
63. Heilmann CJ, Sorgo AG, Mohammadi S, Sosinska GJ, de Koster CG, Brul S, de Koning LJ, Klis FM: Surface stress induces a conserved cell wall stress response in the pathogenic fungus Candida albicans. Eukaryot Cell 2013, 12(2):254-264.

64. Gil-Bona A, Parra-Giraldo CM, Hernaez ML, Reales-Calderon JA, Solis NV, Filler SG, Monteoliva L, Gil C: Candida albicans cell shaving uncovers new proteins involved in cell wall integrity, yeast to hypha transition, stress response and host-pathogen interaction. J Proteomics 2015.

65. Marin E, Parra-Giraldo CM, Hernandez-Haro C, Hernaez ML, Nombela C, Monteoliva L, Gil C: Candida albicans shaving to profile human serum proteins on hyphal surface. Front Microbiol 2015, 6:1343.

66. Hernaez ML, Ximenez-Embun P, Martinez-Gomariz M, Gutierrez-Blazquez MD, Nombela C, Gil C: Identification of Candida albicans exposed surface proteins in vivo by a rapid proteomic approach. J Proteomics 2010, 73(7):1404-1409.

67. Martinez-Gomariz M, Perumal P, Mekala S, Nombela C, Chaffin WL, Gil C: Proteomic analysis of cytoplasmic and surface proteins from yeast cells, hyphae, and biofilms of Candida albicans. Proteomics 2009, 9(8):2230-2252.

68. Vialas V, Perumal P, Gutierrez D, Ximenez-Embun P, Nombela C, Gil C, Chaffin WL: Cell surface shaving of Candida albicans biofilms, hyphae, and yeast form cells. Proteomics 2012, 12(14):2331-2339.

69. Pitarch A, Jimenez A, Nombela C, Gil C: Serological proteome analysis to identify systemic candidiasis patients in the intensive care unit: Analytical, diagnostic and prognostic validation of anti-Candida enolase antibodies on quantitative clinical platforms. PROTEOMICS - Clinical Applications 2008, 2(4):596-618.

70. Sarthy AV, McGonigal T, Coen M, Frost DJ, Meulbroek JA, Goldman RC: Phenotype in Candida albicans of a disruption of the BGL2 gene encoding a 1,3-beta-glucosyltransferase. Microbiology 1997, 143 ( Pt 2):367-376.

71. Taff HT, Nett JE, Zarnowski R, Ross KM, Sanchez H, Cain MT, Hamaker J, Mitchell AP, Andes DR: A Candida biofilm-induced pathway for matrix glucan delivery: implications for drug resistance. Plos Pathog 2012, 8(8):e1002848.

72. Ene IV, Heilmann CJ, Sorgo AG, Walker LA, de Koster CG, Munro CA, Klis FM, Brown AJ: Carbon source-induced reprogramming of the cell wall proteome and secretome modulates the adherence and drug resistance of the fungal pathogen Candida albicans. Proteomics 2012, 12(21):3164-3179.

73. Silva RC, Padovan AC, Pimenta DC, Ferreira RC, da Silva CV, Briones MR: Extracellular enolase of Candida albicans is involved in colonization of mammalian intestinal epithelium. Front Cell Infect Microbiol 2014, 4:66.

74. Jong AY, Chen SH, Stins MF, Kim KS, Tuan TL, Huang SH: Binding of Candida albicans enolase to plasmin(ogen) results in enhanced invasion of human brain microvascular endothelial cells. J Med Microbiol 2003, 52(Pt 8):615-622.

75. Pitarch A, Nombela C, Gil C: Candida albicans biology and pathogenicity: insights from proteomics. Methods Biochem Anal 2006, 49:285-330.

76. Crowe JD, Sievwright IK, Auld GC, Moore NR, Gow NA, Booth NA: Candida albicans binds human plasminogen: identification of eight plasminogen-binding proteins. Mol Microbiol 2003, 47(6):1637-1651.

77. Alloush HM, Lopez-Ribot JL, Masten BJ, Chaffin WL: 3-phosphoglycerate kinase: a glycolytic enzyme protein present in the cell wall of Candida albicans. Microbiology 1997, 143 ( Pt 2):321-330.

78. Hasim S, Hussin NA, Alomar F, Bidasee KR, Nickerson KW, Wilson MA: A glutathione-independent glyoxalase of the DJ-1 superfamily plays an important role in managing metabolically generated methylglyoxal in Candida albicans. J Biol Chem 2014, 289(3):1662-1674.

79. Cabello L, Gomez-Herreros E, Fernandez-Pereira J, Maicas S, Martinez-Esparza MC, de Groot PWJ, Valentin E: Deletion of GLX3 in Candida albicans affects temperature tolerance, biofilm formation and virulence. FEMS Yeast Res 2019, 19(2).

80. Joo MY, Shin JH, Jang HC, Song ES, Kee SJ, Shin MG, Suh SP, Ryang DW: Expression of SAP5 and SAP9 in Candida albicans biofilms: comparison of bloodstream isolates with isolates from other sources. Med Mycol 2013, 51(8):892-896.

81. Mochon AB, Jin Y, Kayala MA, Wingard JR, Clancy CJ, Nguyen MH, Felgner P, Baldi P, Liu H: Serological profiling of a Candida albicans protein microarray reveals permanent host-pathogen interplay and stage-specific responses during candidemia. Plos Pathog 2010, 6(3):e1000827. 
82. Viudes A, Lazzell A, Perea S, Kirkpatrick WR, Peman J, Patterson TF, Martinez JP, Lopez-Ribot JL: The C-terminal antibody binding domain of Candida albicans mp58 represents a protective epitope during candidiasis. FEMS Microbiology Letters 2004, 232(2):133-138.

83. Luo S, Dasari P, Reiher N, Hartmann A, Jacksch S, Wende E, Barz D, Niemiec MJ, Jacobsen I, Beyersdorf N et al: The secreted Candida albicans protein Pra1 disrupts host defense by broadly targeting and blocking complement C3 and C3 activation fragments. Mol Immunol 2018, 93:266-277.

84. Gomez MJ, Torosantucci A, Arancia S, Maras B, Parisi L, Cassone A: Purification and biochemical characterization of a 65kilodalton mannoprotein (MP65), a main target of anti-Candida cell-mediated immune responses in humans. Infect Immun 1996, 64(7):2577-2584.

85. Hiller E, Heine S, Brunner H, Rupp S: Candida albicans Sun41p, a putative glycosidase, is involved in morphogenesis, cell wall biogenesis, and biofilm formation. Eukaryot Cell 2007, 6(11):2056-2065.

86. McCreath KJ, Specht CA, Robbins PW: Molecular cloning and characterization of chitinase genes from Candida albicans. Proc Natl Acad Sci U S A 1995, 92(7):2544-2548.

87. Bromuro C, Torosantucci A, Gomez MJ, Urbani F, Cassone A: Differential release of an immunodominant 65 kDa mannoprotein antigen from yeast and mycelial forms of Candida albicans. Journal of Medical and Veterinary Mycology 1994, 32(6):447-459.

88. Lisowska E: The role of glycosylation in protein antigenic properties. Cellular and Molecular Life Sciences 2002, 59(3):445-455.

89. Martínez JP, Gil ML, López-Ribot JL, Chaffin WL: Serologic response to cell wall mannoproteins and proteins of Candida albicans. Clin Microbiol Rev 1998, 11(1):121-141.

90. Pardo M, Ward M, Pitarch A, Sanchez M, Nombela C, Blackstock W, Gil C: Cross-species identification of novel Candida albicans immunogenic proteins by combination of two-dimensional polyacrylamide gel electrophoresis and mass spectrometry. Electrophoresis 2000, 21(13):2651-2659.

91. Torosantucci A, Tumbarello M, Bromuro C, Chiani P, Posteraro B, Sanguinetti M, Cauda R, Cassone A: Antibodies against a beta-glucan-protein complex of Candida albicans and its potential as indicator of protective immunity in candidemic patients. Sci Rep 2017, 7(1):2722. 